\title{
Emergy efficiency of land-use systems in the brazilian semi-arid region
}

Emergy analysis is used to evaluate agricultural management systems in order to diagnose their efficiency in using economic and natural resources. In this study, emergy analysis was used to evaluate an agroforestry production model and compare it to the traditional production model used in the semi-arid region of the northeast of Brazil. The agroforestry model comprises three subsystems: agrosilvopastoral (ASP), silvopastoral (SP) and preserved caatinga (CAT). For the traditional model, three subsystems were evaluated: an area under cultivation (AC); an area lying fallow for six years (F6); and an area fallow for nine years (F9). For each model and its respective subsystems, all input and output energy flows were identified. These flows were later quantified and transformed into emergy using their respective transformity values. The emergy performance of the systems and subsystems was evaluated by the indices: transformity later quantified and transformed into emergy using their respective transformity values. The emergy performance of the systems and subsystems was evaluated by the indices: transformity
(Tr), emergy investment ratio (EIR), emergy yield ratio (EYR), emergy renewability index (\%R), environmental load rate (ELR), and emergy sustainability index (ESI). It was found that the agroforestry model uses a lower quantity $(-13 \%)$ of natural resources than the traditional model. However, the agroforestry model uses $64 \%$ more resources from the economy than used in AC. More than $55 \%$ of the emergy required in the ASP and AC subsystems comes from services. The subsystems that required a greater amount of emergy and achieved less efficiency were $\mathrm{SP}$ in the agroforestry model and AG in the traditional model. Values for Tr were lower in CAT (2.6E+03) and higher in AC (2.4E+05). The ELR was low in all areas, ranging from 0.00 in F6 and F9 to 0.58 in SP. Values for \%R ranged from 60.76 in AC to 99.98 in F6. The agroforestry system displayed better emergy performance due to a lower values for Tr and ELR, and greater renewability.

Keywords: Agroforestry systems; Emergy; Sustainability index; Caatinga; Integrated production.

\section{Eficiência emergética de sistemas de uso da terra na região semiárida brasileira}

\begin{abstract}
A análise emergética é utilizada para avaliar sistemas de manejo agrícola a fim de diagnosticar sua eficiência no uso dos recursos econômicos e naturais. Neste sentido, a análise emergética foi utilizada com o objetivo de avaliar um modelo de produção agroflorestal, comparativamente ao modelo de produção tradicional utilizado na região semiárida nordestina. 0 modelo agroflorestal é composto de três subsistemas: agrossilvopastoril (ASP), silvopastoril (SP) e caatinga conservda (CAT). No modelo tradicional avaliou-se três subsistemas: área em cultivo (AG); área em pousio a seis anos (P6) e área em pousio a nove anos (P9). Em cada modelo e seus respectivos subsistemas, foram identificados todos os fluxos de entrada e saída de energia. área em pousio a seis anos (P6) e área em pousio a nove anos (P9). Em cada modelo e seus respectivos subsistemas, foram identificados todos os fluxos de entrada e saída de energia. Posteriormente estes fluxos foram quantificados e transformados em emergia utilizando seus respectivos valores de transformidade. O desempenho emergético dos sistemas e subsistemas
foi avaliado por meio dos índices: transformidade (Tr), razão de investimento emergético (EIR), razão de rendimento emergético (EYR), índice de Renovabilidade emergética (\%R), taxa de carga ambiental (ELR) e índice de sustentabilidade emergética. Observou-se que o modelo agroflorestal utiliza menor quantidade (-13\%) de recursos naturais do que o modelo tradicional. No entanto, o modelo agroflorestal utiliza $64 \%$ a mais dos recursos da economia utilizado em AG. Mais de $55 \%$ da emergia demandada nos subsistemas ASP e AG é proveniente de serviços. Os subsistemas que demandam maior quantidade de emergia e obtiveram menor eficiência foram o SP, do modelo agroflorestal, e o AG, do modelo tradicional. Os valores de Tr foram menores em CAT (2,6E+03) e maiores em AG (2,4E+05). O ELR foram baixos em todas as áreas, variando de 0,00 em P6 e P9 à 0,58 em SP. Os valores de R(\%) variaram de 60,76 em AG á 99,98 em P6. O sistema agroflorestal teve melhor desempenho emergético devido sua menor Tr, menor ELR e maior renovabilidade.
\end{abstract}

Palavras-chave: Sistemas Agroflorestal; Emergia; Índices de sustentabilidade; Caatinga; Produção Integrada.

Topic: Desenvolvimento, Sustentabilidade e Meio Ambiente

Reviewed anonymously in the process of blind peer.

Maria Ivanilda de Aguiar (D)

Universidade da Integração Internacional da Lusofonia Afro Brasileira, Brasil http://lattes.cnpq.br/5455983813192128

http://orcid.org/0000-0002-6147-2621

ivanilda@unilab.edu.br

Mônica Matoso Campanha id

Embrapa Milho e Sorgo, Brasil

http://lattes.cnpq.br/0443286008669758

http://orcid.org/0000-0001-7133-5439

monica.matoso@embrapa.br

Teógenes Senna de Oliveira (iD)

Universidade Federal de Viçosa, Brasil

http://lattes.cnpq.br/3516356640355770

http://orcid.org/0000-0002-9904-6708

teo@ufv.br
Received: 05/10/2020

Approved: 26/11/2020

\section{Referencing this:}

AGUIAR, M. I.; CAMPANHA, M. M.; OLIVEIRA, T. S.. Emergy efficiency of land-use systems in the brazilian semi-arid region. Revista lbero Americana de Ciências Ambientais, v.11, n.6, p.568-582, 2020. DOI: http://doi.org/10.6008/CBPC2179-6858.2020.006.0046 


\section{INTRODUCTION}

Emergy Systems Theory, developed over three decades ago (ODUM, 1994; 1996), provides a unit (emjoule) and a method (Emergy Analysis) to enable the conversion of all energy flows from different sources and of different types, into a common unit (ODUM, 1996). The conversion of the different flows to solar emjoules is achieved by multiplying the available value in its original unit $(\mathrm{J}, \mathrm{kg}, \$ \$)$ by its respective solar transformity value (seJ/unit). Transformity is defined as the solar radiation directly or indirectly required to create another available form of energy (ODUM, 1996), i.e. the energy spent in the production process of any given product. Several authors have used emergy analysis to evaluate and compare different agricultural and/or livestock systems (CAVALETT et al., 2009; LU et al., 2009; AGOSTINHO et al., 2008; 2010; ALFAROARGUELLO et al., 2010; EURICH et al., 2013; FONSECA et al., 2016). Some of these studies demonstrate the efficiency of agricultural properties that adopt concepts of agroecology in the transformation of energy, indicating a greater use of renewable resources, a coexistence with nature and economic profitability (ORTEGA et al., 2005; FRANCESCATTO et al., 2008; AGOSTINHO et al., 2010; WU et al., 2015).

In this respect, agroforestry systems (AFSs) are considered as viable alternatives for sustainable agroecological production. AFSs are land-use systems in which traditional crops are intercropped with trees and/or animals, with a better spatial and temporal use of the agroecosystem components (NAIR, 1993). Such systems have been studied as an alternative to traditional agricultural management adopted by farmers in the semi-arid region of Brazil (ARAÚJO FILHO et al., 2001; DRUMOND et al., 2004; MARIN et al., 2006). Araújo Filho et al. (2001) describe a system that aims to conserve native vegetation and increase agricultural productivity by integrating agricultural, forestry and pastoral activities. In this systems, the area is subdivided into three plots: one kept as a reserve of native caatinga and the others used for grazing and grain production respectively. The two managed areas preserve a percentage of the native tree cover (from $20 \%$ to $38 \%$ ), and the growing area has legume alleys (leucaena and gliricidia), used as a protein bank for animals and as green manure. Several studies have been carried out in these areas highlighting such positive aspects of AFSs as: improved soil quality (NOGUEIRA et al., 2008; SILVA et al., 2011; FIALHO et al., 2013); reduced water erosion (AGUIAR et al., 2010); greater production and addition of plant biomass to the soil (AGUIAR et al., 2014); maintaining plant diversity (AGUIAR et al., 2013); greater crop productivity (ARAÚJO FILHO et al, 2001) and economic viability in sheep production (BLOC et al., 2016). However, these studies were carried out using original indicators and units. There is a lack of holistic assessment of the ecological and economic effects of the system, which would use a general unit and integrate the different properties of the systems, analysing them as a set.

To this effect, several authors emphasise the importance of carrying out the emergy analysis of agricultural systems considering the different production units as subsystems, and thereby checking the internal flows of each subsystem, their contribution in relation to the system as a whole, and their coproducts, such as changes in soil quality, and their effects on the agroecosystem (LU et al., 2006; WU et al., 2015; FONSECA et al., 2016). Such an evaluation would allow a better definition of the levels of sustainability 
of the AFSs, and may be possible using the emergy concept proposed by Odum (1996). The aim here therefore, is to carry out the emergy analysis of an agroforestry production model (and its subsystems) proposed for the semi-arid region of the northeast, comparing it with the production model traditionally used in the region.

\section{MATERIALS AND METHODS}

\section{Study areas}

The study areas are located on the Crioula Farm, of the National Centre for Goat and Sheep Research (CNPCO) of EMBRAPA, in Sobral, in the State of Ceará, Brazil. The mean annual temperature and rainfall for the town of Sobral are from $26^{\circ} \mathrm{C}$ to $28^{\circ} \mathrm{C}$, and $821.6 \mathrm{~mm}$ respectively, with a rainy season from January to May (IPECE, 2016). The climate is tropical dry equatorial, very hot and semi-arid, type BSw'h' according to the Köppen classification (BRASIL, 1981). The soil in the experimental area (9582600S - 9583600S and 352200W - 352800W) is represented by patches of a typic Orthic Chromic Luvisol and typic Orthic Hypochromic Luvissol (AGUIAR et al., 2010). The vegetation is composed of a thorny, deciduous savanna, known in the region as Caatinga (COLE, 1960).

Since 1997, a long-term experiment has been under development to evaluate AFSs as sustainable production systems, proposed as alternatives to the traditional systems of the region (ARAÚJO FILHO et al, 2001). The agroforestry model (AGROF) is composed of three subsystems: Agrosilvipastoral (ASP), where maize and sorghum are grown in alleys formed by leucaena and gliricidia; Silvopastoral (SP), a thinned and cut back area of caatinga, used for grazing goats and sheep; and an area of preserved caatinga (CAT), kept as a reserve. The traditional model (TRAD) consists of the deforestation and burning of all native vegetation followed by two years' cultivation (slash and burn agriculture). After two years of cultivation, the area is left fallow and a new plot is used for planting. The areas used in this management are made up of one plot (1.0 ha) under cultivation and several others at different periods of fallow. From this management system, one area under the traditional cultivation (AC) of monocrops of maize and sorghum, and two fallow areas of six and nine years (F6 and F9) respectively, were selected. The cropping systems and management history of the areas are described in Aguiar et al. (2013).

\section{Emergy analysis}

Emergy analysis was carried out as per Odum (1996; 2000), and Brown et al (2004), in three stages, which consisted of constructing system diagrams of the areas, quantifying the components of the energy flow and calculating the emergy indices. The system diagrams were elaborated following the systems language of Odum (1996). The diagrams demarcate the boundaries of management systems and organise the relationship between the collected data, including flows, interactions and stocks, of the mass and energy identified in each area. Diagrams representing the managements (AGROF and TRAD) and their respective subsystems were elaborated. The contribution of the energy flow components was obtained in earlier 
studies, and converted into terms of solar emergy joules using their respective values for transformity.

Identified flows were classified for their origin in renewable natural resources, non-renewable natural resources, and economic, service and product resources (ODUM, 1996). The partial renewability of materials and services was considered, as per Ortega (2002) and Agostinho et al. (2008). Emergy gain or loss from improved soil quality was obtained by comparing the carbon and nitrogen stocks of the microbial biomass, of the soil organic matter, and the losses through erosion in the managed subsystems, with those occurring in the area of native vegetation (CAT). An improvement in soil quality was quantified as a coproduct, while a loss in soil quality was considered (lost) energy used in the production process, as per Lu et al. (2006). Data on inputs and production were collected on site during 2010 and 2011. Mean annual rainfall data for the previous ten years, obtained in the study areas, were considered. The values for solar radiation and wind speed were compiled from the National Meteorological Institute - INMET (INMET, 2012).

The emergy performance of the systems was evaluated using the following indices: transformity (Tr), emergy investment ratio (EIR), emergy yield ratio (EYR), emergy renewability index (\%R), environmental loading rate (ELR) and emergy sustainability index (ESI) (ULGIATI et al., 1995; ODUM, 1996; BROWN et al., 1997; ORTEGA, 2002). A brief explanation and the formulas by which these indices are obtained are shown in Table 1.

Table 1: Indices used in the emergy analysis

\begin{tabular}{|c|c|c|}
\hline Index & Formula & Interpretation \\
\hline Transformity (Tr) & $\mathrm{Y} / \mathrm{E}$ & $\begin{array}{l}\text { Total incorporated energy ( } \mathrm{Y} \text {; emergy) used per } \\
\text { generated-product energy ( } \mathrm{E}) \text {. Evaluates the } \\
\text { quality of the energy flow and efficiency of the } \\
\text { system. }\end{array}$ \\
\hline $\begin{array}{l}\text { Emergy yield ratio } \\
\text { (EYR) }\end{array}$ & $\mathrm{Y} / \mathrm{F}$ & $\begin{array}{l}\text { Contribution of the energy from economic } \\
\text { resources }(F) \text { in relation to total energy. Enables } \\
\text { the net benefit to be known. }\end{array}$ \\
\hline $\begin{array}{l}\text { Emergy investment } \\
\text { ratio }\end{array}$ & $F / I$ & $\begin{array}{l}\text { Measures re-introduced energy from the } \\
\text { economic sector }(F) \text { in relation to energy inputs } \\
\text { from the environment }(I)\end{array}$ \\
\hline Renewability (\%R) & {$\left[\left(R+M_{R}+S_{R}\right) / Y\right]^{*} 100$} & $\begin{array}{l}\text { Contribution of energy from renewable } \\
\text { resources (R) over total energy. Refers to } \\
\text { system sustainability. }\end{array}$ \\
\hline $\begin{array}{l}\text { Environmental loading } \\
\text { rate (ELR) }\end{array}$ & $\left(N+M_{N}+S_{N}\right) /\left(R+M_{R}+S_{R}\right)$ & $\begin{array}{l}\text { Ratio between non-renewable and renewable } \\
\text { energies. Indicates the level of technology used } \\
\text { and the impact on the environment caused by } \\
\text { the systems. }\end{array}$ \\
\hline $\begin{array}{l}\text { Emergy sustainability } \\
\text { index (ESI) }\end{array}$ & EYR/ELR & $\begin{array}{l}\text { Ratio of emergy yield ratio to environmental } \\
\text { load rate. Indicates system sustainability. }\end{array}$ \\
\hline
\end{tabular}

Source: Ulgiati et al., 1995; Odum, 1996; Brown and Ulgiati, 1997; Ortega, 2002; $\mathrm{Y}=\mathrm{I}+\mathrm{F} ; \mathrm{I}=\mathrm{R}+\mathrm{N} ; \mathrm{F}=\mathrm{M}+\mathrm{S} ; \mathrm{Y}=$ total energy; $\mathrm{I}=$ natural resources; $\mathrm{F}=$ market resources; $\mathrm{R}=$ energy from renewable resources; $\mathrm{N}=$ energy from nonrenewable resources; $M$ = energy from materials; $S$ = energy from services;

\section{RESULTS AND DISCUSSION}

Diagrams of the areas and identification of emergency flows

The renewable natural resources that support the subsystems (Figures 1 and 2) come from the sun, rain, geological uplift, soil microbiota [carbon and nitrogen from the microbial biomass (MBC and MBN)], soil organic matter (OM) and from the nutrients $(\mathrm{N}, \mathrm{P}, \mathrm{K}, \mathrm{Ca}$ and $\mathrm{Mg}$ ) available in the soil. The soil components 
were considered as renewable natural resources, since their use has not caused any reduction in quantity when compared to the preserved caatinga (AGUIAR et al., 2014). This indicates that the use of these resources by the system does not exceed the process of geological production, and are therefore renewable (AGOSTINHO et al., 2008).

In addition to the renewable natural resources, under the agroforestry management (Figure 1), the ASP subsystem uses energy from services (manpower) and materials, such as seeds and manure (with the manure coming from the SP subsystem). In this subsystem there were losses of non-renewable natural resources due to a reduction in soil quality and to erosion, which reduces soil organic matter and minerals. In ASP, in addition to the production of maize and sorghum, the biomass stored by the trees, herbaceous plants and litter were evaluated as products, together with the grazing biomass from native tree regrowth and introduced legumes. Furthermore, due to the presence of trees, this area may favour infiltration due to lower erosion losses (AGUIAR et al., 2010). The presence of trees in the system also provides food and shelter for wildlife, in addition to providing greater thermal comfort (RONCON et al., 2012). It is emphasised that of these products, only grazing biomass and biomass produced by crops (maize and sorghum) are exported from this subsystem, and are supplied to the SP subsystem (Figure 1). On the other hand, ASP maintains its regeneration potential due to the permanence of the native trees, which however, are always kept at an intermediate stage of succession by weeding and cutting, to allow the cultivation of maize and sorghum. The regeneration potential for this and for the other subsystems was included in diagram (Figure 1) but not quantified, due to the methodological difficulties of measuring its transformability, since the calculations are of a high level of complexity.

The SP subsystem is maintained by the same flows as the ASP, with the addition of the products necessary for animal management, such as medicines, vaccines, feed, silage and water (Figure 1). The silage used comes from the maize and sorghum produced in the ASP subsystem (Figure 1). The SP management favours the internal stocks of biomass and plant richness, providing an improvement in soil quality as a byproduct. It also provides manure for the area of ASP, and meat that is marketed locally. As in ASP, the presence of native trees retains the regeneration potential of the area, although the type of management maintains a constant level of disruption to favour a greater production of herbaceous biomass (Aguiar et al., 2013), necessary for feeding the animals.

The subsystem maintained under native caatinga (CAT) expresses the system in its natural condition (Figure 1). In this subsystem, the flows and stocks of energy interact in their sustainable form, as this is maintained by natural resources, and by the stocks and natural recycling of nutrients from the litter and soil. The products of the system are infiltrated water, surface and subsurface runoff, shelter and food for the fauna, and an increase in tree biomass and grazing biomass. According to the proposed agroforestry system, this sub-area also provides plant biomass for the animals of the SP subsystem (Figure 1); in the same way, manpower is also used as energy input, originating in the economy. 


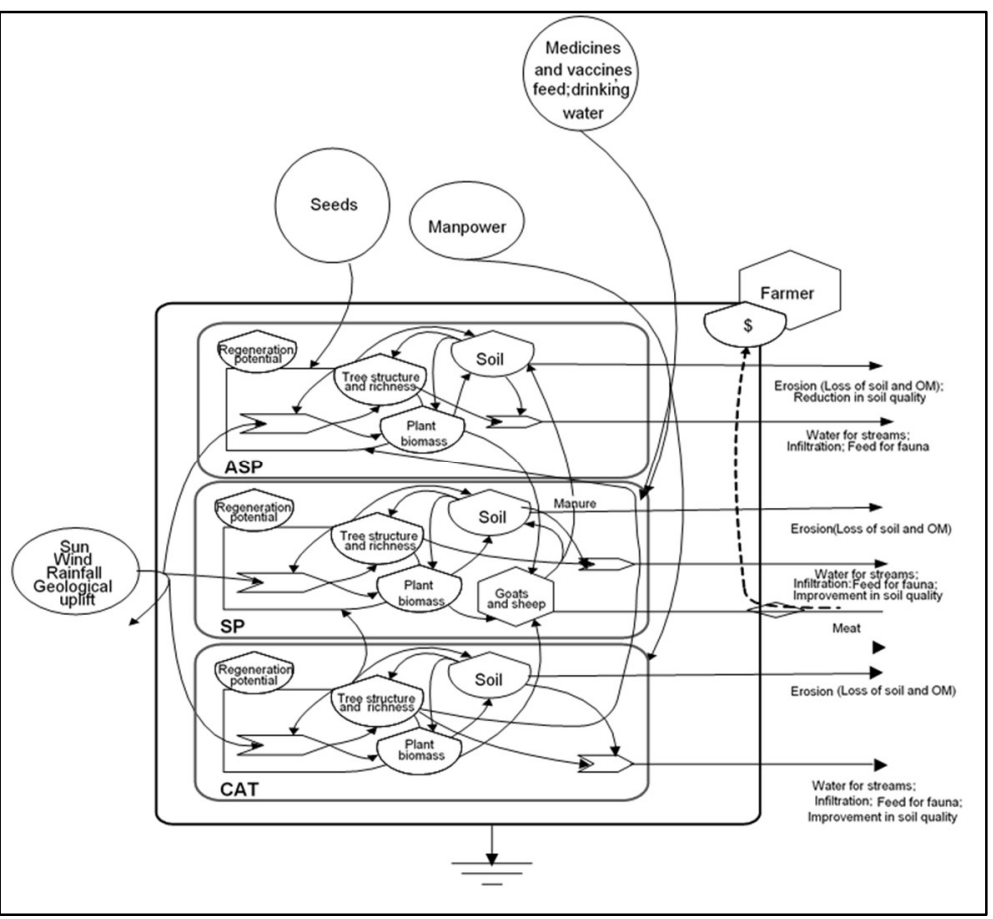

Figure 1: Emergy flows of the agroforestry production system. ASP: agrosylvopastoral; SP: silvopastoral; CAT: preserved caatinga.

Under the traditional management (Figure 2), energy from natural resources and from the economy (seeds and manpower) is used. This energy is used for crop production (maize and sorghum). However, the production process in this system (AC) causes greater soil loss due to erosion, a reduction in soil quality and the loss of tree structure and richness. The loss of soil quality, and of organic matter and nutrients, were quantified as non-renewable natural resources necessary to the production process. Edaphic structure and richness were also considered as losses, however they were not quantified, due to methodological difficulties in calculating their transformity. Part of the lost tree biomass remains in the system as ash. The dynamics of this subsystem provide little stock over time, as all the biomass contained in the vegetation is lost when planting the crop, and the biomass produced by the crop is constantly removed by collecting the grain and the crop residue, which is consumed by the animals. During the first two years of use, the area displays no regeneration potential, since anthropic intervention prevents any increase in richness, or the development of tree-structure (AGUIAR et al., 2013; 2019) and edaphic stocks (SILVA et al., 2011; FIALHO et al., 2013; AGUIAR et al., 2014). As the soil remains uncovered for much of the year, it is assumed that the kinetic energy of the rain, together with the wind, reaches the soil directly, intensifying the loss due to erosion (AGUIAR et al., 2010).

The traditional fallow subsystems (F6 and F9) (Figure 2), just like CAT, are in their natural form, being dependent entirely on natural resources. As products, they present tree biomass, litter and an improvement in soil quality (seen only in F6). The two fallow areas are in a process of recovery, and present different dynamics; thus, it was seen that in F9 the reduction in soil quality due to traditional cultivation is still noticeable. These areas also favour infiltration, supply water to streams due to runoff, and provide shelter and food for wildlife. From lying fallow, the regeneration potential of the areas is recovered, and a contribution to plant richness and an increase in tree (AGUIAR et al., 2013) and edaphic (FIALHO et al., 2013; 
AGUIAR et al., 2014) diversity and structure is promoted (AGUIAR et al., 2013, 2019). It can be seen that in the traditional production model there is no interaction between the cultivated areas and the fallow areas (Figure 2), due to the sequence of cultivation followed by fallow.

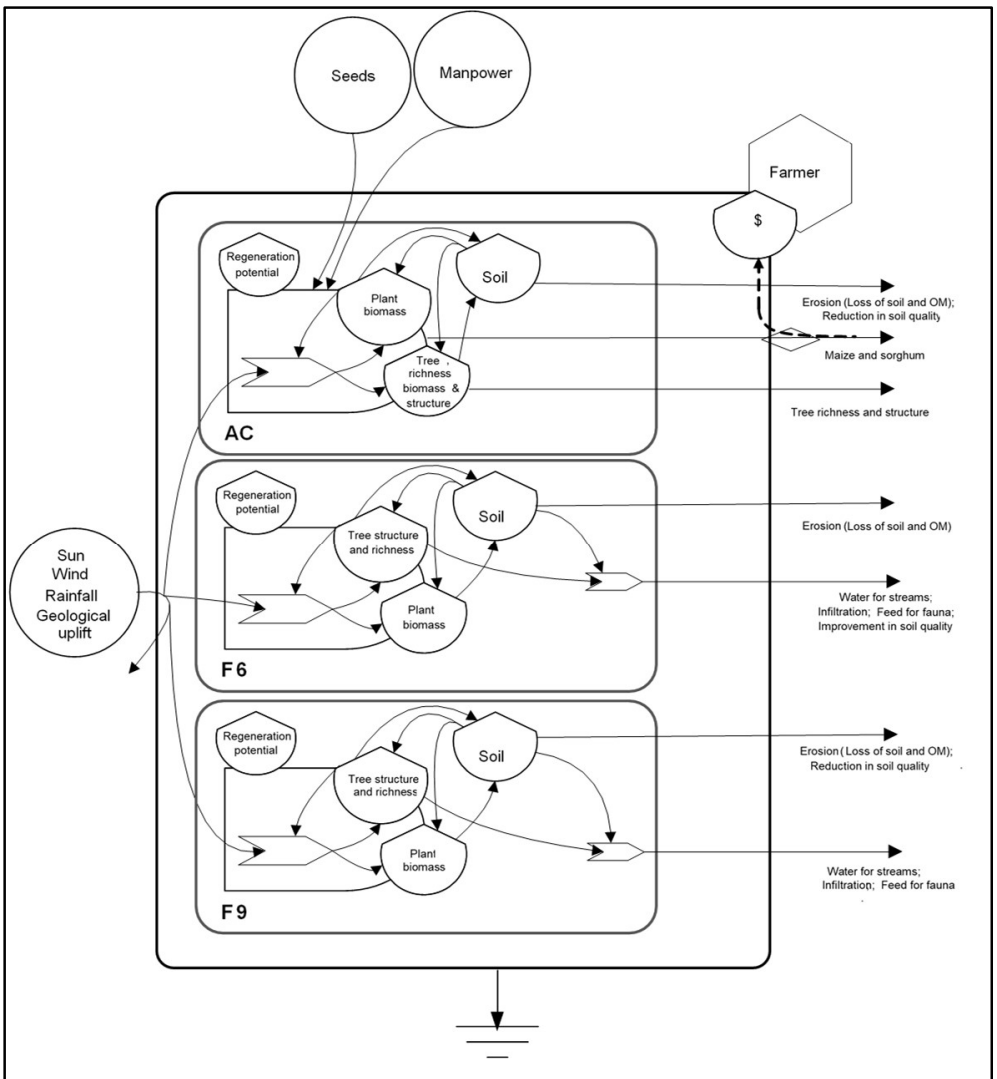

Figure 2: Emergy flows for the traditional production system. AC: traditional cultivation; F6: six years of fallow after traditional cultivation; F9: nine years of fallow after traditional cultivation.

\section{Components of the energy flow}

Of the natural resources used in the two systems, rainfall accounted for more than $40 \%$ of the emergy input from renewable resources (Tables 2 and 3). Rainfall energy is responsible for solubilising and transporting nutrients between the systems, favouring development of the biota and maintaining the physical and chemical quality of the soil, however its kinetic energy, together with the wind, can directly reach the soil in areas with little ground cover and intensify the erosion process. In areas where there is good plant cover however, the kinetic energy of the rain is used by the system, since on being blocked by the plant canopy, it optimises photosynthesis, due to the removal of dust and residue from the leaves (RONCON et al., 2012).

Other renewable natural resources that contributed greatly to the functioning of the systems under evaluation, were geological uplift, MBC and total soil N. Geological uplift is responsible for the geological processes that act upon the formation of soil structure (ODUM, 2000). The greatest emergy contributions (rainfall, geological uplift, MBN and total soil $\mathrm{N}$ ) occur due to higher transformity values and/or a greater availability of the resource per unit of energy (Tables 2 and 3 ).

The subsystems behaved differently in their demand for non-renewable natural resources. In the agroforestry system, for the ASP subsystem, the greatest use of emergy was due to the loss of soil quality, 
while in SP, it was due to the use of drinking water; in CAT soil erosion was responsible for the high emergy consumption (Table 2). In the traditional model, the highest consumption of non-renewable natural resources occurred due to loss of soil quality (in AC and F9), erosion (in F6) and ashes (in AC) (Table 3).

The greatest amount of emergy consumed from economic resources, was the manpower used by the ASP and CAT agroforestry subsystems (Table 2) and traditional.

Table 2: Emergy evaluation of the agroforestry system

\begin{tabular}{|c|c|c|c|c|c|c|c|c|c|c|}
\hline \multirow{2}{*}{$\begin{array}{l}\text { Not } \\
\mathrm{e}\end{array}$} & \multirow[t]{2}{*}{ Item (unit*) } & \multicolumn{4}{|c|}{ Value/ha/year } & \multirow{2}{*}{$\begin{array}{l}\text { Transform } \\
\text { ity } \\
\text { (seJ/unit) } \\
\text { (ref.) }\end{array}$} & \multicolumn{4}{|c|}{ Emergy flow (seJ/ha/year) } \\
\hline & & ASP & SP & CAT & $\begin{array}{l}\text { AGRO } \\
\mathrm{F}\end{array}$ & & ASP & SP & CAT & $\begin{array}{l}\text { AGRO } \\
\mathrm{F}\end{array}$ \\
\hline \multicolumn{11}{|c|}{ Renewable resources $(\mathrm{R})$} \\
\hline 1 & Sun $(J)$ & $\begin{array}{l}5.8 \mathrm{E}+1 \\
3\end{array}$ & $\begin{array}{l}5.8 \mathrm{E}+ \\
13\end{array}$ & $\begin{array}{l}5.8 \mathrm{E}+1 \\
3\end{array}$ & $\begin{array}{l}5.8 \mathrm{E}+ \\
13\end{array}$ & $\begin{array}{l}1.0 \mathrm{E}+00 \\
\text { (a) }\end{array}$ & $\begin{array}{l}5.8 \mathrm{E}+ \\
13\end{array}$ & $\begin{array}{l}5.8 \mathrm{E}+ \\
13\end{array}$ & $\begin{array}{l}5.8 \mathrm{E}+ \\
13\end{array}$ & $\begin{array}{l}5.8 \mathrm{E}+ \\
13\end{array}$ \\
\hline 2 & Rainfall (J) & $\begin{array}{l}4.9 \mathrm{E}+1 \\
0\end{array}$ & $\begin{array}{l}4.9 \mathrm{E}+ \\
10\end{array}$ & $\begin{array}{l}4.9 \mathrm{E}+1 \\
0\end{array}$ & $\begin{array}{l}4.9 \mathrm{E}+ \\
10\end{array}$ & $\begin{array}{l}3.1 \mathrm{E}+04 \\
\text { (b) }\end{array}$ & $\begin{array}{l}1.5 \mathrm{E}+ \\
15\end{array}$ & $\begin{array}{l}1.5 \mathrm{E}+ \\
15\end{array}$ & $\begin{array}{l}1.5 \mathrm{E}+ \\
15\end{array}$ & $\begin{array}{l}1.5 \mathrm{E}+ \\
15\end{array}$ \\
\hline 3 & Wind $(J)$ & $\begin{array}{l}1.1 \mathrm{E}+0 \\
9\end{array}$ & $\begin{array}{l}1.1 \mathrm{E}+ \\
09\end{array}$ & $\begin{array}{l}1.1 \mathrm{E}+0 \\
9\end{array}$ & $\begin{array}{l}1.1 \mathrm{E}+ \\
09\end{array}$ & $\begin{array}{l}2.5 \mathrm{E}+03 \\
\text { (b) }\end{array}$ & $\begin{array}{l}2.7 \mathrm{E}+ \\
12\end{array}$ & $\begin{array}{l}2.7 \mathrm{E}+ \\
12\end{array}$ & $\begin{array}{l}2.7 \mathrm{E}+ \\
12\end{array}$ & $\begin{array}{l}2.7 \mathrm{E}+ \\
12\end{array}$ \\
\hline 4 & Geological uplift (J) & $\begin{array}{l}4.5 \mathrm{E}+1 \\
0\end{array}$ & $\begin{array}{l}4.5 E+ \\
10\end{array}$ & $\begin{array}{l}4.5 E+1 \\
0\end{array}$ & $\begin{array}{l}4.5 \mathrm{E}+ \\
10\end{array}$ & $\begin{array}{l}1.2 \mathrm{E}+04 \\
\text { (a) }\end{array}$ & $\begin{array}{l}5.4 \mathrm{E}+ \\
14\end{array}$ & $\begin{array}{l}5.4 \mathrm{E}+ \\
14\end{array}$ & $\begin{array}{l}5.4 \mathrm{E}+ \\
14\end{array}$ & $\begin{array}{l}5.4 \mathrm{E}+ \\
14\end{array}$ \\
\hline \multirow[t]{9}{*}{5} & Soil quality & & & & & & & & & \\
\hline & $\mathrm{MBC}(\mathrm{J})$ & $\begin{array}{l}6.4 \mathrm{E}+0 \\
9\end{array}$ & $\begin{array}{l}6.8 \mathrm{E}+ \\
09\end{array}$ & $\begin{array}{l}8.7 E+0 \\
9\end{array}$ & $\begin{array}{l}7.3 \mathrm{E}+ \\
09\end{array}$ & $\begin{array}{l}5.7 E+04 \\
\text { (c) }\end{array}$ & $\begin{array}{l}3.6 \mathrm{E}+ \\
14\end{array}$ & $\begin{array}{l}3.9 \mathrm{E}+ \\
14\end{array}$ & $\begin{array}{l}4.9 \mathrm{E}+ \\
14\end{array}$ & $\begin{array}{l}4.2 \mathrm{E}+ \\
14\end{array}$ \\
\hline & $\operatorname{MBN}(J)$ & $\begin{array}{l}1.1 \mathrm{E}+0 \\
9\end{array}$ & $\begin{array}{l}1.4 \mathrm{E}+ \\
09\end{array}$ & $\begin{array}{l}1.5 \mathrm{E}+0 \\
9\end{array}$ & $\begin{array}{l}1.3 \mathrm{E}+ \\
09\end{array}$ & $\begin{array}{l}5.7 \mathrm{E}+04 \\
\text { (c) }\end{array}$ & $\begin{array}{l}6.5 E+ \\
13\end{array}$ & $\begin{array}{l}7.7 E+ \\
13\end{array}$ & $\begin{array}{l}8.8 \mathrm{E}+ \\
13\end{array}$ & $\begin{array}{l}7.7 \mathrm{E}+ \\
13\end{array}$ \\
\hline & OM (J) & $\begin{array}{l}9.6 \mathrm{E}+1 \\
1\end{array}$ & $\begin{array}{l}1.8 \mathrm{E}+ \\
12\end{array}$ & $\begin{array}{l}1.37 \mathrm{E}+ \\
12\end{array}$ & $\begin{array}{l}1.4 \mathrm{E}+ \\
12\end{array}$ & $\begin{array}{l}1.5 \mathrm{E}+02 \\
\text { (c) }\end{array}$ & $\begin{array}{l}1.4 \mathrm{E}+ \\
14\end{array}$ & $\begin{array}{l}2.7 \mathrm{E}+ \\
14\end{array}$ & $\begin{array}{l}2.0 \mathrm{E}+ \\
14\end{array}$ & $\begin{array}{l}2.1 \mathrm{E}+ \\
14\end{array}$ \\
\hline & Total N (kg) & $\begin{array}{l}2.5 \mathrm{E}+0 \\
3\end{array}$ & $\begin{array}{l}3.6 \mathrm{E}+ \\
03\end{array}$ & $\begin{array}{l}3.2 \mathrm{E}+0 \\
3\end{array}$ & $\begin{array}{l}3.1 \mathrm{E}+ \\
03\end{array}$ & $\begin{array}{l}1.6 \mathrm{E}+11 \\
\text { (c) }\end{array}$ & $\begin{array}{l}3.9 \mathrm{E}+ \\
14\end{array}$ & $\begin{array}{l}5.7 E+ \\
14\end{array}$ & $\begin{array}{l}5.1 \mathrm{E}+ \\
14\end{array}$ & $\begin{array}{l}4.9 \mathrm{E}+ \\
14\end{array}$ \\
\hline & Available P (kg) & $\begin{array}{l}2.5 E+0 \\
1\end{array}$ & $\begin{array}{l}6.3 \mathrm{E}+ \\
00\end{array}$ & $\begin{array}{l}6.1 E+0 \\
0\end{array}$ & $\begin{array}{l}1.2 \mathrm{E}+ \\
01\end{array}$ & $\begin{array}{l}3.4 E+09 \\
\text { (c) }\end{array}$ & $\begin{array}{l}8.5 E+ \\
10\end{array}$ & $\begin{array}{l}2.2 \mathrm{E}+ \\
10\end{array}$ & $\begin{array}{l}2.1 \mathrm{E}+ \\
10\end{array}$ & $\begin{array}{l}4.2 \mathrm{E}+ \\
10\end{array}$ \\
\hline & Exchangeable $\mathrm{K}(\mathrm{kg})$ & $\begin{array}{l}3.2 \mathrm{E}+0 \\
2\end{array}$ & $\begin{array}{l}4.4 \mathrm{E}+ \\
02\end{array}$ & $\begin{array}{l}3.1 \mathrm{E}+0 \\
2\end{array}$ & $\begin{array}{l}3.6 \mathrm{E}+ \\
02\end{array}$ & $\begin{array}{l}1.6 \mathrm{E}+09 \\
\text { (c) }\end{array}$ & $\begin{array}{l}5.1 \mathrm{E}+ \\
11\end{array}$ & $\begin{array}{l}7.1 \mathrm{E}+ \\
11\end{array}$ & $\begin{array}{l}4.9 \mathrm{E}+ \\
11\end{array}$ & $\begin{array}{l}5.7 \mathrm{E}+ \\
11\end{array}$ \\
\hline & Exchangeable $\mathrm{Ca}(\mathrm{kg})$ & $2.9 \mathrm{E}+0$ & $2.9 \mathrm{E}+$ & $4.4 \mathrm{E}+0$ & $3.4 \mathrm{E}+$ & $4.7 \mathrm{E}+09$ & $1.4 \mathrm{E}+$ & $1.4 \mathrm{E}+$ & $2.1 \mathrm{E}+$ & $1.6 \mathrm{E}+$ \\
\hline & Exchangeable Mg (kg) & $\begin{array}{l}5.9 E+0 \\
2\end{array}$ & $\begin{array}{l}7.1 \mathrm{E}+ \\
02\end{array}$ & $\begin{array}{l}8.1 E+0 \\
2\end{array}$ & $\begin{array}{l}7.1 \mathrm{E}+ \\
02\end{array}$ & $\begin{array}{l}3.3 E+09 \\
\text { (c) }\end{array}$ & $\begin{array}{l}2.0 \mathrm{E}+ \\
12\end{array}$ & $\begin{array}{l}2.4 \mathrm{E}+ \\
12\end{array}$ & $\begin{array}{l}2.7 \mathrm{E}+ \\
12\end{array}$ & $\begin{array}{l}15 \\
2.3 \mathrm{E}+ \\
12\end{array}$ \\
\hline \multicolumn{11}{|c|}{ Non-renewable resources (N) } \\
\hline 6 & Drinking water $(\mathrm{J})$ & $\begin{array}{l}0.0 \mathrm{E}+0 \\
0\end{array}$ & $\begin{array}{l}3.7 \mathrm{E}+ \\
07\end{array}$ & $\begin{array}{l}0.0 \mathrm{E}+0 \\
0\end{array}$ & $\begin{array}{l}1.2 \mathrm{E}+ \\
07\end{array}$ & $\begin{array}{l}6.7 E+05 \\
\text { (d) }\end{array}$ & $\begin{array}{l}0.0 \mathrm{E}+ \\
00\end{array}$ & $\begin{array}{l}2.4 \mathrm{E}+ \\
13\end{array}$ & $\begin{array}{l}0.0 \mathrm{E}+ \\
00\end{array}$ & $\begin{array}{l}8.2 \mathrm{E}+ \\
12\end{array}$ \\
\hline \multirow[t]{2}{*}{7} & Soil erosion $(\mathrm{OM})(\mathrm{J})$ & $\begin{array}{l}2.6 \mathrm{E}+0 \\
8\end{array}$ & $\begin{array}{l}1.9 \mathrm{E}+ \\
08\end{array}$ & $\begin{array}{l}7.7 E+0 \\
8\end{array}$ & $\begin{array}{l}4.1 \mathrm{E}+ \\
08\end{array}$ & $\begin{array}{l}1.5 \mathrm{E}+02 \\
\text { (c) }\end{array}$ & $\begin{array}{l}3.9 \mathrm{E}+ \\
10\end{array}$ & $\begin{array}{l}2.8 \mathrm{E}+ \\
10\end{array}$ & $\begin{array}{l}1.2 \mathrm{E}+ \\
11\end{array}$ & $\begin{array}{l}6.1 \mathrm{E}+ \\
10\end{array}$ \\
\hline & Soil erosion $_{\text {(mineral fraction) }}(\mathrm{J})$ & $\begin{array}{l}3.5 E+0 \\
2\end{array}$ & $\begin{array}{l}1.6 \mathrm{E}+ \\
02\end{array}$ & $\begin{array}{l}6.7 E+0 \\
2\end{array}$ & $\begin{array}{l}3.9 \mathrm{E}+ \\
02\end{array}$ & $\begin{array}{l}1.0 \mathrm{E}+09 \\
\text { (e) }\end{array}$ & $\begin{array}{l}3.5 \mathrm{E}+ \\
11\end{array}$ & $\begin{array}{l}1.6 \mathrm{E}+ \\
11\end{array}$ & $\begin{array}{l}6.7 E+ \\
11\end{array}$ & $\begin{array}{l}3.9 \mathrm{E}+ \\
11\end{array}$ \\
\hline 8 & Loss of soil quality (J) & $\begin{array}{l}4.1 \mathrm{E}+1 \\
1\end{array}$ & $\begin{array}{l}0.0 \mathrm{E}+ \\
00\end{array}$ & $\begin{array}{l}0.0 \mathrm{E}+0 \\
0\end{array}$ & $\begin{array}{l}1.4 \mathrm{E}+ \\
11\end{array}$ & $2.2 E+04(f)$ & $\begin{array}{l}9.0 \mathrm{E}+ \\
15\end{array}$ & $\begin{array}{l}0.0 \mathrm{E}+ \\
00\end{array}$ & $\begin{array}{l}0.0 \mathrm{E}+ \\
00\end{array}$ & $\begin{array}{l}3.0 \mathrm{E}+ \\
15\end{array}$ \\
\hline \multicolumn{11}{|c|}{ Economic resources (F) } \\
\hline 9 & Manure (kg) & $\begin{array}{l}2.3 E+0 \\
3\end{array}$ & $\begin{array}{l}2.3 \mathrm{E}+ \\
03\end{array}$ & $\begin{array}{l}0.0 \mathrm{E}+0 \\
0\end{array}$ & $\begin{array}{l}0.0 \mathrm{E}+ \\
00\end{array}$ & $\begin{array}{l}3.0 \mathrm{E}+12 \\
(\mathrm{~g})\end{array}$ & $\begin{array}{l}6.7 \mathrm{E}+ \\
15\end{array}$ & $\begin{array}{l}6.7 \mathrm{E}+ \\
15\end{array}$ & $\begin{array}{l}0.0 \mathrm{E}+ \\
00\end{array}$ & $\begin{array}{l}0.0 \mathrm{E}+ \\
00\end{array}$ \\
\hline 10 & Grazing biomass (J) & $\begin{array}{l}0.0 \mathrm{E}+0 \\
0\end{array}$ & $\begin{array}{l}8.0 \mathrm{E}+ \\
10\end{array}$ & $\begin{array}{l}0.0 \mathrm{E}+0 \\
0\end{array}$ & $\begin{array}{l}0.0 \mathrm{E}+ \\
00\end{array}$ & $5.5 E+03(f)$ & $\begin{array}{l}0.0 \mathrm{E}+ \\
00\end{array}$ & $\begin{array}{l}4.4 \mathrm{E}+ \\
14\end{array}$ & $\begin{array}{l}0.0 \mathrm{E}+ \\
00\end{array}$ & $\begin{array}{l}0.0 \mathrm{E}+ \\
00\end{array}$ \\
\hline 11 & Maize silage $(\mathrm{J})$ & $\begin{array}{l}0.0 \mathrm{E}+0 \\
0\end{array}$ & $\begin{array}{l}4.2 E+ \\
10\end{array}$ & $\begin{array}{l}0.0 \mathrm{E}+0 \\
0\end{array}$ & $\begin{array}{l}0.0 \mathrm{E}+ \\
00\end{array}$ & $\begin{array}{l}1.0 E+06 \\
\text { (a) }\end{array}$ & $\begin{array}{l}0.0 \mathrm{E}+ \\
00\end{array}$ & $\begin{array}{l}4.3 E+ \\
16\end{array}$ & $\begin{array}{l}0.0 \mathrm{E}+ \\
00\end{array}$ & $\begin{array}{l}0.0 \mathrm{E}+ \\
00\end{array}$ \\
\hline 12 & Sorghum silage (J) & $\begin{array}{l}0.0 \mathrm{E}+0 \\
0\end{array}$ & $\begin{array}{l}7.1 \mathrm{E}+ \\
10\end{array}$ & $\begin{array}{l}0.0 \mathrm{E}+0 \\
0\end{array}$ & $\begin{array}{l}0.0 \mathrm{E}+ \\
00\end{array}$ & $\begin{array}{l}6.0 E+05 \\
\text { (a) }\end{array}$ & $\begin{array}{l}0.0 \mathrm{E}+ \\
00\end{array}$ & $\begin{array}{l}4.3 \mathrm{E}+ \\
16\end{array}$ & $\begin{array}{l}0.0 \mathrm{E}+ \\
00\end{array}$ & $\begin{array}{l}0.0 \mathrm{E}+ \\
00\end{array}$ \\
\hline 13 & Seeds (kg) & $\begin{array}{l}1.3 E+0 \\
1\end{array}$ & $\begin{array}{l}0.0 \mathrm{E}+ \\
00\end{array}$ & $\begin{array}{l}0.0 \mathrm{E}+0 \\
0\end{array}$ & $\begin{array}{l}4.4 \mathrm{E}+ \\
00\end{array}$ & $\begin{array}{l}1.5 \mathrm{E}+12 \\
\text { (d) }\end{array}$ & $\begin{array}{l}2.0 \mathrm{E}+ \\
13\end{array}$ & $\begin{array}{l}0.0 \mathrm{E}+ \\
00\end{array}$ & $\begin{array}{l}0.0 \mathrm{E}+ \\
00\end{array}$ & $\begin{array}{l}6.6 \mathrm{E}+ \\
12\end{array}$ \\
\hline 14 & $\begin{array}{l}\text { Medicines and vaccines } \\
\text { (U\$\$) }\end{array}$ & $\begin{array}{l}0.0 \mathrm{E}+0 \\
0\end{array}$ & $\begin{array}{l}7.5 \mathrm{E}+ \\
02\end{array}$ & $\begin{array}{l}0.0 \mathrm{E}+0 \\
0\end{array}$ & $\begin{array}{l}2.5 \mathrm{E}+ \\
02\end{array}$ & $\begin{array}{l}3.7 E+12 \\
\text { (d) }\end{array}$ & $\begin{array}{l}0.0 \mathrm{E}+ \\
00\end{array}$ & $\begin{array}{l}2.8 \mathrm{E}+ \\
15\end{array}$ & $\begin{array}{l}0.0 \mathrm{E}+ \\
00\end{array}$ & $\begin{array}{l}9.2 \mathrm{E}+ \\
14\end{array}$ \\
\hline 15 & Supplementary feed (U\$\$) & $\begin{array}{l}0.0 \mathrm{E}+0 \\
0\end{array}$ & $\begin{array}{l}1.9 \mathrm{E}+ \\
03\end{array}$ & $\begin{array}{l}0.0 \mathrm{E}+0 \\
0\end{array}$ & $\begin{array}{l}6.4 \mathrm{E}+ \\
02\end{array}$ & $\begin{array}{l}3.3 \mathrm{E}+12 \\
(\mathrm{~g})\end{array}$ & $\begin{array}{l}0.0 \mathrm{E}+ \\
00\end{array}$ & $\begin{array}{l}6.3 \mathrm{E}+ \\
15\end{array}$ & $\begin{array}{l}0.0 \mathrm{E}+ \\
00\end{array}$ & $\begin{array}{l}2.1 \mathrm{E}+ \\
15\end{array}$ \\
\hline 16 & Manpower (J) & $\begin{array}{l}1.3 \mathrm{E}+0 \\
9\end{array}$ & $\begin{array}{l}6.8 \mathrm{E}+ \\
08\end{array}$ & $\begin{array}{l}2.8 \mathrm{E}+0 \\
7\end{array}$ & $\begin{array}{l}6.7 \mathrm{E}+ \\
08\end{array}$ & $1.9 \mathrm{E}+07(\mathrm{i})$ & $\begin{array}{l}2.4 \mathrm{E}+ \\
16\end{array}$ & $\begin{array}{l}1.3 \mathrm{E}+ \\
16\end{array}$ & $\begin{array}{l}5.2 \mathrm{E}+ \\
14 \\
\end{array}$ & $\begin{array}{l}1.2 \mathrm{E}+ \\
16\end{array}$ \\
\hline
\end{tabular}




\begin{tabular}{|c|c|c|c|c|c|c|c|c|c|c|}
\hline & Specialized manpower $(\mathrm{J})$ & $8.0 \mathrm{E}+0$ & $2.1 \mathrm{E}+$ & $2.7 \mathrm{E}+0$ & $1.1 \mathrm{E}+$ & $2.8 \mathrm{E}+06$ (i) & $2.2 \mathrm{E}+$ & $5.9 \mathrm{E}+$ & $7.6 \mathrm{E}+$ & $3.0 \mathrm{E}+$ \\
\hline & & 6 & 07 & 6 & 07 & & 13 & 13 & 12 & 13 \\
\hline \multirow[t]{7}{*}{17} & Increase & $1.0 \mathrm{E}+1$ & $8.2 \mathrm{E}+$ & $9.0 \mathrm{E}+1$ & $9.1 \mathrm{E}+$ & & $5.6 \mathrm{E}+$ & $4.5 \mathrm{E}+$ & $5.0 \mathrm{E}+$ & $5.0 \mathrm{E}+$ \\
\hline & biomass (tree+herbaceous) $_{(\mathrm{J})}$ & 1 & 10 & 0 & 10 & $5.5 \mathrm{E}+03(f)$ & 14 & 14 & 14 & 14 \\
\hline & Grazing & $1.7 \mathrm{E}+1$ & $2.5 \mathrm{E}+$ & $4.2 \mathrm{E}+0$ & $0.0 \mathrm{E}+$ & & $9.4 \mathrm{E}+$ & $1.4 \mathrm{E}+$ & $2.4 \mathrm{E}+$ & $0.0 \mathrm{E}+$ \\
\hline & biomass(herbaceous+regrowth) $(\mathrm{J})$ & 0 & 10 & 9 & 00 & $5.5 \mathrm{E}+03(\mathrm{f})$ & 13 & 14 & 13 & 00 \\
\hline & & $3.4 \mathrm{E}+1$ & $0.0 \mathrm{E}+$ & $0.0 \mathrm{E}+0$ & $0.0 \mathrm{E}+$ & & $1.9 \mathrm{E}+$ & $0.0 \mathrm{E}+$ & $0.0 \mathrm{E}+$ & $0.0 \mathrm{E}+$ \\
\hline & Legume biomass $(\mathrm{J})$ & 0 & 00 & 0 & 00 & $5.5 \mathrm{E}+03(\mathrm{f})$ & 14 & 00 & 00 & 00 \\
\hline & & $3.0 \mathrm{E}+1$ & $3.2 \mathrm{E}+$ & $5.4 \mathrm{E}+1$ & $3.9 \mathrm{E}+$ & & $1.7 \mathrm{E}+$ & $1.8 \mathrm{E}+$ & $3.0 \mathrm{E}+$ & $2.2 \mathrm{E}+$ \\
\hline \multirow[t]{4}{*}{18} & Litter $_{\text {(biomass) }}(\mathrm{J})$ & 0 & 10 & 0 & 10 & $5.5 E+03(f)$ & 14 & 14 & 14 & 14 \\
\hline & & $1.1 \mathrm{E}+0$ & $9.4 \mathrm{E}+$ & $2.0 \mathrm{E}+0$ & $1.4 \mathrm{E}+$ & $2.1 \mathrm{E}+11$ & $2.4 \mathrm{E}+$ & $2.0 \mathrm{E}+$ & $4.2 \mathrm{E}+$ & $2.9 \mathrm{E}+$ \\
\hline & $\operatorname{Litter}_{(\mathrm{N}+\mathrm{P}+\mathrm{K}+\mathrm{Ca}+\mathrm{Mg})}(\mathrm{kg})$ & 2 & 01 & 2 & 02 & (c) & 13 & 13 & 13 & 13 \\
\hline & Improvement in soil quality & $0.0 \mathrm{E}+0$ & $4.3 \mathrm{E}+$ & $1.4 \mathrm{E}+1$ & $6.0 \mathrm{E}+$ & & $0.0 \mathrm{E}+$ & $9.4 \mathrm{E}+$ & $3.0 \mathrm{E}+$ & $1.3 \mathrm{E}+$ \\
\hline \multirow[t]{2}{*}{19} & (J) & 0 & 11 & 2 & 11 & $2.2 \mathrm{E}+04(\mathrm{f})$ & 00 & 15 & 16 & 16 \\
\hline & & $0.0 \mathrm{E}+0$ & $4.6 \mathrm{E}+$ & $0.0 \mathrm{E}+0$ & $0.0 \mathrm{E}+$ & $3.0 \mathrm{E}+12$ & $0.0 \mathrm{E}+$ & $1.3 \mathrm{E}+$ & $0.0 \mathrm{E}+$ & $0.0 \mathrm{E}+$ \\
\hline \multirow[t]{2}{*}{20} & Manure (Kg) & 0 & 03 & 0 & 00 & (g) & 00 & 16 & 00 & 00 \\
\hline & & $4.2 \mathrm{E}+1$ & $0.0 \mathrm{E}+$ & $0.0 \mathrm{E}+0$ & $0.0 \mathrm{E}+$ & $1.0 E+06$ & $4.3 \mathrm{E}+$ & $0.0 \mathrm{E}+$ & $0.0 \mathrm{E}+$ & $0.0 \mathrm{E}+$ \\
\hline 21 & Maize (J) & 0 & 00 & 0 & 00 & (a) & 16 & 00 & 00 & 00 \\
\hline \multirow{3}{*}{22} & & $7.1 \mathrm{E}+1$ & $0.0 \mathrm{E}+$ & $0.0 \mathrm{E}+0$ & $0.0 \mathrm{E}+$ & $6.0 E+05$ & $4.3 \mathrm{E}+$ & $0.0 \mathrm{E}+$ & $0.0 \mathrm{E}+$ & $0.0 \mathrm{E}+$ \\
\hline & Sorghum (J) & 0 & 00 & 0 & 00 & (a) & 16 & 00 & 00 & 00 \\
\hline & & $0.0 \mathrm{E}+0$ & $6.2 \mathrm{E}+$ & $0.0 \mathrm{E}+0$ & $2.1 \mathrm{E}+$ & $5.2 E+07$ & $0.0 \mathrm{E}+$ & $3.2 \mathrm{E}+$ & $0.0 \mathrm{E}+$ & $1.1 \mathrm{E}+$ \\
\hline 23 & Meat $(\mathrm{J})$ & 0 & 08 & 0 & 08 & (a) & 00 & 16 & 00 & 16 \\
\hline
\end{tabular}

ref .: references for transformity; (a) Odum (2000); (b) Brawn et al (2004); (C) Roncon et al. (2012); (d) Ortega (2002); (e) Odum (1996); (f) Lu et al. (2006); (g) Coelho et al (2003); MBC: Microbial biomass carbon; MBN: Microbial biomass nitrogen; OM: Organic matter; ASP: Agrosilvopastoral; SP: silvopastoral; CAT: Preserved caatinga; Agroforestry production model, comprising the ASP, SP and CAT subsystems.

*Conversion: [Solar radiation (INMET, 2012): $1929.51 \mathrm{kWh} \mathrm{m}^{-2} \times 10000 \mathrm{~m}^{2} \mathrm{ha}^{-1} \times 3.6 \mathrm{E}+6 \mathrm{~J} \mathrm{kWh}^{-1} \times(100-17$ (albedo Palácio et al. 2013)/100]; [rainfall: $0.989 \mathrm{~m}^{3} \mathrm{~m}^{-2} \times 10000 \mathrm{~m}^{2} \mathrm{ha}^{-1} \times 1000 \mathrm{dm}^{3} \mathrm{~m}^{-3} \times 1 \mathrm{~kg} \mathrm{dm}^{-3} \times 4940 \mathrm{~J} \mathrm{~kg}^{-1}$ (Odum, 2000)]; [Wind velocity m s$~^{-1}$ (INMET, 2012): $2.67 \times 10000 \mathrm{~m}^{2} \mathrm{ha}^{-1} \times 3.13 \mathrm{E}+7 \mathrm{~s} \mathrm{year}^{-1} \times 1.3 \mathrm{~kg} \mathrm{~m}^{-3}$ (Rodriguez et al., 2002) $\times 0.001$ (Rodriguez et al., 2002) x 1,09E+9 $\mathrm{J} \mathrm{ha}^{-1}$; [ [Geological uplift (Odum, 2000): $6.71 \mathrm{E}+20 \mathrm{~J} \mathrm{year}^{-1} \times 1,49 \mathrm{E}+10 \mathrm{ha}$; [Soil quality: MBC; MBN; OM kg ha-1 (Fialho et al., 2013) x $5400 \mathrm{kcal} \mathrm{kg}^{-1} \times 4187 \mathrm{~J} \mathrm{kcal}^{-1}$; Total N; Available P; Exchangeable K; Ca e Mg $\mathrm{kg} \mathrm{ha}^{-1}$ (Aguiar et al. 2014)]; [Soil erosion(mo): soil loss in kg ha-1 (Aguiar et al., 2010) $\times \mathrm{OM} \mathrm{kg} \mathrm{kg}^{-1}$ (Aguiar et al., 2010) $x$ $5400 \mathrm{kcal} \mathrm{kg}^{-1} \times 4187 \mathrm{~J} \mathrm{kcal}^{-1}$; soil erosion (organic fraction): soil loss in kg ha-1 (Aguiar et al., 2010) $\times 5400 \mathrm{kcal} \mathrm{kg}^{-1} \times 4187 \mathrm{~J} \mathrm{kcal}^{-}$ 1. soil erosion(oм)]; [Grazing biomass kg ha- year $^{-1}$ (Carvalho, 2003) x $3.4 \mathrm{E}+3 \mathrm{kcal} \mathrm{kg}^{-1}$; [Manpower: dailyrate ha-1 year $^{-1}$ $\times 2.5 \mathrm{E}+3 \mathrm{kcal}$ dailyrate $\mathrm{e}^{-1} \times 4186 \mathrm{~J} \mathrm{kcal}^{-1}$; [ [ncrease in biomass(treetherbaceous): biomass t ha ${ }^{-1} \mathrm{year}^{-1}$ (Aguiar et al., 2013) $\times 1000$ $\mathrm{kg} \mathrm{t}^{-1} \times 3.4 \mathrm{E}+3 \mathrm{kcal} \mathrm{kg}^{-1} \times 4186 \mathrm{~J} \mathrm{kcal}^{-1}$; [ [Legume biomass: $2100 \mathrm{~kg} \mathrm{ha}^{-1} \times 0.91 \times 4213.3 \mathrm{kcal} \mathrm{kg}^{-1} \times 4186 \mathrm{~J} \mathrm{kcal}^{-1}$ ]; [Litter(biomass): biomass kg ha-1 (Aguiar et al., 2014) $x$ dry matter (\%) biomass energy kcal kg-1 x $4186 \mathrm{~J} \mathrm{kcal}^{-1}$ ];

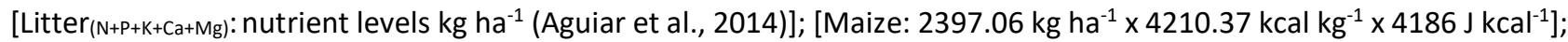
[Sorghum: $4133.49 \mathrm{~kg} \mathrm{ha}^{-1} \times 4110.65 \mathrm{kcal} \mathrm{kg}^{-1} \times 4186 \mathrm{~J} \mathrm{kcal}^{-1}$ ]; [Meat: $42.49 \mathrm{~kg} \mathrm{ha}^{-1} \times 3500 \mathrm{kcal} \mathrm{kg}^{-1} \times 4186 \mathrm{~J} \mathrm{kcal}^{-1}$ ].

Table 3: Emergy evaluation of the traditional system

\begin{tabular}{|c|c|c|c|c|c|c|c|c|c|c|}
\hline \multirow{2}{*}{ Note } & \multirow{2}{*}{ Item (unit) } & \multicolumn{4}{|c|}{ Value/ha/year } & \multirow{2}{*}{$\begin{array}{l}\text { ansformity } \\
\text { (seJ/unit) } \\
\text { (ref.) }\end{array}$} & \multicolumn{4}{|c|}{ Emergy flow (seJ/ha/year) } \\
\hline & & $A C$ & F6 & F9 & TRAD & & $A C$ & F6 & F9 & TRAD \\
\hline \multicolumn{11}{|c|}{ Renewable resources ( $R$ ) } \\
\hline 1 & $\operatorname{Sun}(J)$ & $5.8 \mathrm{E}+13$ & $5.8 \mathrm{E}+13$ & $5.8 \mathrm{E}+13$ & $5.8 \mathrm{E}+13$ & $1.0 \mathrm{E}+00(\mathrm{a})$ & $5.8 \mathrm{E}+13$ & $5.8 \mathrm{E}+13$ & $5.8 \mathrm{E}+13$ & $5.8 \mathrm{E}+13$ \\
\hline 2 & Rainfall (J) & $4.9 \mathrm{E}+10$ & $4.9 \mathrm{E}+10$ & $4.9 \mathrm{E}+10$ & $4.9 \mathrm{E}+10$ & $3.1 \mathrm{E}+04(\mathrm{~b})$ & $1.5 \mathrm{E}+15$ & $1.5 \mathrm{E}+15$ & $1.5 \mathrm{E}+15$ & $1.5 \mathrm{E}+15$ \\
\hline 3 & Wind $(J)$ & $1.1 \mathrm{E}+09$ & $1.1 \mathrm{E}+09$ & $1.1 \mathrm{E}+09$ & $1.1 \mathrm{E}+09$ & $2.5 E+03(b)$ & $2.7 \mathrm{E}+12$ & $2.7 \mathrm{E}+12$ & $2.7 E+12$ & $2.7 \mathrm{E}+12$ \\
\hline 4 & Geological uplift (J) & $4.5 \mathrm{E}+10$ & $4.5 \mathrm{E}+10$ & $4.5 \mathrm{E}+10$ & $4.5 \mathrm{E}+10$ & $1.2 \mathrm{E}+04(\mathrm{a})$ & $5.4 \mathrm{E}+14$ & $5.4 \mathrm{E}+14$ & $5.4 \mathrm{E}+14$ & $5.4 \mathrm{E}+14$ \\
\hline \multirow[t]{9}{*}{5} & Soil quality & & & & & & & & & \\
\hline & $\mathrm{MBC}(J)$ & $5.7 \mathrm{E}+09$ & $8.0 \mathrm{E}+09$ & $8.3 \mathrm{E}+09$ & $7.4 \mathrm{E}+09$ & $5.7 \mathrm{E}+04(\mathrm{c})$ & $3.3 \mathrm{E}+14$ & $4.6 \mathrm{E}+14$ & 4.7E+14 & $4.2 \mathrm{E}+14$ \\
\hline & $\operatorname{MBN}(J)$ & $1.4 \mathrm{E}+09$ & $2.4 \mathrm{E}+09$ & $2.2 \mathrm{E}+09$ & $2.0 \mathrm{E}+09$ & $5.7 \mathrm{E}+04(\mathrm{c})$ & $7.9 E+13$ & $1.3 \mathrm{E}+14$ & $1.2 \mathrm{E}+14$ & $1.1 \mathrm{E}+14$ \\
\hline & $\mathrm{OM}(\mathrm{J})$ & $1.2 \mathrm{E}+12$ & $1.4 \mathrm{E}+12$ & $1.3 \mathrm{E}+12$ & $1.3 \mathrm{E}+12$ & $1.5 \mathrm{E}+02$ (c) & 1.7E+14 & $2.2 \mathrm{E}+14$ & $1.9 \mathrm{E}+14$ & $1.9 \mathrm{E}+14$ \\
\hline & Total N (kg) & $2.7 E+03$ & $3.1 \mathrm{E}+03$ & $2.9 \mathrm{E}+03$ & $2.9 \mathrm{E}+03$ & $1.6 \mathrm{E}+11(\mathrm{c})$ & $4.2 E+14$ & $4.9 \mathrm{E}+14$ & 4.7E+14 & $4.6 \mathrm{E}+14$ \\
\hline & Available P (kg) & $1.7 \mathrm{E}+01$ & $1.3 \mathrm{E}+01$ & $4.3 \mathrm{E}+00$ & $1.1 \mathrm{E}+01$ & $3.4 \mathrm{E}+09(\mathrm{c})$ & $5.8 \mathrm{E}+10$ & $4.4 \mathrm{E}+10$ & $1.4 \mathrm{E}+10$ & $3.9 \mathrm{E}+10$ \\
\hline & Exchangeable $\mathrm{K}(\mathrm{kg})$ & $4.8 \mathrm{E}+02$ & $4.1 \mathrm{E}+02$ & $2.7 E+02$ & $3.8 \mathrm{E}+02$ & $1.6 \mathrm{E}+09(\mathrm{c})$ & $7.7 \mathrm{E}+11$ & $6.5 \mathrm{E}+11$ & $4.3 E+11$ & $6.1 \mathrm{E}+11$ \\
\hline & Exchangeable $\mathrm{Ca}(\mathrm{kg})$ & $3.2 \mathrm{E}+03$ & $6.6 \mathrm{E}+03$ & $1.9 \mathrm{E}+03$ & $3.9 E+03$ & $4.7 \mathrm{E}+09(\mathrm{c})$ & $1.5 E+13$ & $3.1 \mathrm{E}+13$ & $9.1 \mathrm{E}+12$ & $1.8 \mathrm{E}+13$ \\
\hline & Exchangeable Mg (kg) & $1.1 \mathrm{E}+03$ & $1.3 E+03$ & $9.3 \mathrm{E}+02$ & $1.1 \mathrm{E}+03$ & $3.3 \mathrm{E}+09(\mathrm{c})$ & $3.6 \mathrm{E}+12$ & $4.3 E+12$ & $3.1 \mathrm{E}+12$ & $3.7 \mathrm{E}+12$ \\
\hline \multicolumn{11}{|c|}{ Non-renewable resources (N) } \\
\hline \multirow[t]{3}{*}{6} & Soil erosion $\mathrm{OMM}_{(\mathrm{J})}$ & $1.2 \mathrm{E}+09$ & $5.2 \mathrm{E}+08$ & $5.2 \mathrm{E}+08$ & $7.5 \mathrm{E}+08$ & $1.5 \mathrm{E}+02(\mathrm{c})$ & $1.8 \mathrm{E}+11$ & $7.8 \mathrm{E}+10$ & $7.8 \mathrm{E}+10$ & $1.1 \mathrm{E}+11$ \\
\hline & Soil erosion(mineral fraction) & & & & & & & & & \\
\hline & (J) & $1.5 \mathrm{E}+03$ & $5.0 \mathrm{E}+02$ & $5.0 \mathrm{E}+02$ & $8.2 \mathrm{E}+02$ & $1.0 \mathrm{E}+09(\mathrm{e})$ & $1.5 \mathrm{E}+12$ & $5.0 \mathrm{E}+11$ & $5.0 \mathrm{E}+11$ & $8.2 \mathrm{E}+11$ \\
\hline 7 & Loss of soil quality $(\mathrm{J})$ & $2.1 \mathrm{E}+11$ & $0.0 \mathrm{E}+00$ & $8.2 E+10$ & $9.8 \mathrm{E}+10$ & $2.2 E+04(f)$ & $4.7 E+15$ & $0.0 \mathrm{E}+00$ & $1.8 \mathrm{E}+15$ & $2.2 E+15$ \\
\hline 8 & Ash (kg) & $5.1 \mathrm{E}+03$ & $0.0 \mathrm{E}+00$ & $0.0 \mathrm{E}+00$ & 1.7E+03 & $1.0 \mathrm{E}+12(\mathrm{~d})$ & $5.1 \mathrm{E}+15$ & $0.0 \mathrm{E}+00$ & $0.0 \mathrm{E}+00$ & 1.7E+15 \\
\hline
\end{tabular}




\begin{tabular}{|c|c|c|c|c|c|c|c|c|c|c|}
\hline \multicolumn{11}{|c|}{ Economic resources (F) } \\
\hline 9 & Seeds (kg) & $1.4 \mathrm{E}+01$ & $0.0 \mathrm{E}+00$ & $0.0 \mathrm{E}+00$ & $4.8 \mathrm{E}+00$ & $1.5 \mathrm{E}+12(\mathrm{~d})$ & $2.1 \mathrm{E}+13$ & $0.0 \mathrm{E}+00$ & $0.0 \mathrm{E}+00$ & $7.1 \mathrm{E}+12$ \\
\hline 10 & Manpower (J) & $8.7 \mathrm{E}+08$ & $0.0 \mathrm{E}+00$ & $0.0 \mathrm{E}+00$ & $2.9 E+08$ & $1.9 \mathrm{E}+07(\mathrm{i})$ & $1.6 \mathrm{E}+16$ & $0.0 \mathrm{E}+00$ & $0.0 \mathrm{E}+00$ & $5.4 \mathrm{E}+15$ \\
\hline \multicolumn{11}{|c|}{ Product $(0)$} \\
\hline & Increase & & & & & & & & & \\
\hline 11 & in biomass(tree+herbaceous) $(\mathrm{J})$ & $1.8 \mathrm{E}+10$ & $8.9 E+10$ & $7.7 E+10$ & $6.1 \mathrm{E}+10$ & $7.4 \mathrm{E}+03(f)$ & $1.3 \mathrm{E}+14$ & $6.6 \mathrm{E}+14$ & $5.7 \mathrm{E}+14$ & $4.5 E+14$ \\
\hline \multirow[t]{3}{*}{12} & Litter (biomass) $_{(\mathrm{J})}$ & $5.7 E+09$ & $5.3 \mathrm{E}+10$ & $6.8 \mathrm{E}+10$ & $4.2 \mathrm{E}+10$ & $5.5 E+03(f)$ & $3.2 \mathrm{E}+13$ & $2.9 E+14$ & $3.8 \mathrm{E}+14$ & $2.3 \mathrm{E}+14$ \\
\hline & Litter $_{(\mathrm{N}+\mathrm{P}+\mathrm{K}+\mathrm{Ca}+\mathrm{Mg})}(\mathrm{kg})$ & $1.8 \mathrm{E}+01$ & $1.8 \mathrm{E}+02$ & $2.2 \mathrm{E}+02$ & $1.4 \mathrm{E}+02$ & $2.1 \mathrm{E}+11(\mathrm{c})$ & $3.7 E+12$ & $3.9 E+13$ & $4.6 \mathrm{E}+13$ & $2.9 \mathrm{E}+13$ \\
\hline & Improvement in soil quality & & & & & & & & & \\
\hline 13 & $(\mathrm{~J})$ & $0.0 \mathrm{E}+00$ & $7.5 \mathrm{E}+10$ & $0.0 \mathrm{E}+00$ & $2.5 E+10$ & $2.2 E+04(f)$ & $0.0 E+00$ & $1.7 \mathrm{E}+15$ & $0.0 \mathrm{E}+00$ & $5.5 E+14$ \\
\hline 14 & Maize (J) & $2.2 \mathrm{E}+10$ & $0.0 \mathrm{E}+00$ & $0.0 \mathrm{E}+00$ & $7.4 \mathrm{E}+09$ & $1.3 E+06(a)$ & $2.9 E+16$ & $0.0 \mathrm{E}+00$ & $0.0 \mathrm{E}+00$ & $9.7 E+15$ \\
\hline 15 & Sorghum (J) & $7.6 \mathrm{E}+10$ & $0.0 \mathrm{E}+00$ & $0.0 \mathrm{E}+00$ & $2.5 E+10$ & $3.8 E+05(a)$ & $2.9 \mathrm{E}+16$ & $0.0 \mathrm{E}+00$ & $0.0 \mathrm{E}+00$ & $9.7 E+15$ \\
\hline
\end{tabular}

ref .: references for transformity; (a) Odum (2000); (b) Brawn et al. (2004); (C) Roncon et al. (2012); (d) Ortega (2002); (e) Odum (1996); (f) Lu et al. (2006); (g) Coelho et al. (2003); MBC: Microbial biomass carbon; MBN: Microbial biomass nitrogen; OM: Organic matter; AC: Traditional cultivation; F6: Traditional cultivation lying fallow for six years; F9: Traditional cultivation lying fallow for nine years; TRAD: Traditional produçtion model, comprising the AC, F6 and F9 subsystems.

*Conversion: [Solar radiation (INMET, 2012): $1929.51 \mathrm{kWh} \mathrm{m}^{-2} \times 10000 \mathrm{~m}^{2} \mathrm{ha}^{-1} \times 3.6 \mathrm{E}+6 \mathrm{~J} \mathrm{kWh}^{-1} \times(100-17$ (albedo Palácio et al. (2013)/100]; [Rainfall: $0.989 \mathrm{~m}^{3} \mathrm{~m}^{-2} \times 10000 \mathrm{~m}^{2} \mathrm{ha}^{-1} \times 1000 \mathrm{dm}^{3} \mathrm{~m}^{-3} \times 1 \mathrm{~kg} \mathrm{dm}^{-3} \times 4940 \mathrm{~J} \mathrm{~kg}^{-1}$ (Odum, 2000)]; [Wind velocity $\mathrm{m} \mathrm{s}^{-1}$ (INMET, 2012): $2.67 \times 10000 \mathrm{~m}^{2} \mathrm{ha}^{-1} \times 3.13 \mathrm{E}+7 \mathrm{~s}_{\text {year }}{ }^{-1} \times 1.3 \mathrm{~kg} \mathrm{~m}^{-3}$ (Rodriguez et al., 2002 ) $\times 0.001$ (Rodriguez et al., 2002) x 1,09E+9 $\mathrm{J} \mathrm{ha}^{-1}$ ]; [Geological uplift (Odum, 2000): 6.71E+20 J year-1 x 1,49E+10 ha]; [Soil quality: MBC; MBN; OM kg ha-1 (Fialho et al., 2013) x $5400 \mathrm{kcal} \mathrm{kg}^{-1}$ x $4187 \mathrm{~J} \mathrm{kcal}^{-1}$; Total N; Available P; Exchangeable K; Ca e Mg $\mathrm{kg} \mathrm{ha}^{-1}$ (Aguiar et al. 2014)]; [soil erosion(OM): soil loss in kg ha-1 (Aguiar et al., 2010) x OM kg kg-1 (Aguiar et al., 2010) $\mathrm{x}$ $5400 \mathrm{kcal} \mathrm{kg}^{-1}$ x $4187 \mathrm{~J} \mathrm{kcal}^{-1}$; soil erosion(organic fraction): soil loss in kg ha-1 (Aguiar et al., 2010) $\times 5400 \mathrm{kcal} \mathrm{kg}^{-1} \times 4187 \mathrm{~J} \mathrm{kcal}^{-}$ ${ }^{1}$ - soil loss(OM)]; [Manpower: dailyrate ha-1 year $^{-1} \times 2.5 \mathrm{E}+3 \mathrm{kcal}$ dailyrate ${ }^{-1} \times 4186 \mathrm{~J} \mathrm{kcal}^{-1}$ ]; [Increase in biomass(tree+herbaceous): biomass t ha ${ }^{-1}$ year $^{-1}$ (Aguiar et al., 2013) $\times 1000 \mathrm{~kg} \mathrm{t}^{-1} \times 3.4 \mathrm{E}+3 \mathrm{kcal} \mathrm{kg}^{-1} \times 4186 \mathrm{~J} \mathrm{kcal}^{-1}$ ]; [Litter (biomass): biomass kg ha-1 (Aguiar et al., 2014) x dry matter (\%) biomass energy kcal kg $\left.{ }^{-1} \times 4186 \mathrm{~J} \mathrm{kcal}^{-1}\right]$; [ Litter $_{(\mathrm{N}+\mathrm{P}+\mathrm{K}+\mathrm{Ca}+\mathrm{Mg})}$ : nutrient levels kg ha ${ }^{-1}$ (Aguiar et al., 2014)]; [Maize: $2397.06 \mathrm{~kg} \mathrm{ha}^{-1} \times 4210.37 \mathrm{kcal} \mathrm{kg}^{-1} \times 4186 \mathrm{~J} \mathrm{kcal}^{-1}$ ]; [Sorghum: $4133.49 \mathrm{~kg} \mathrm{ha}^{-1} \times 4110.65$ $\mathrm{kcal} \mathrm{kg}^{-1}$ x $4186 \mathrm{~J} \mathrm{kcal}^{-1}$.

AC subsystem (Table 3). The SP subsystem requires a larger amount of emergy for feeding the herd (maize silage and sorghum) (Table 3), however, it should be noted that this comes from the ASP subsystem, and has a renewable fraction. It is can be seen that for the agroforestry system (AGROF), the greatest demand for emergy from the economy occurs from the need for manpower, however these services are represented by family and local labour, which also has a renewable fraction.

Comparing grain production in ASP and AC, it can be seen that in ASP there is a higher consumption of emergy (Tables 2 and 3); however, ASP provides a greater amount of emergy due to its co-products, such as tree biomass, litter, and the biomass produced by legumes and regrowth. The emergy produced in AC represents only $41.4 \%$ of the emergy produced in ASP.

As for the emergy produced, ASP contributes to a greater extent with the biomass from the maize and sorghum, which together account for $98.8 \%$ of the emergy produced in this subsystem. It should be noted however, that although they represent less than $2 \%$ of the emergy produced, the co-products, biomass and litter, are of great importance for the maintenance of this subsystem and of the system as a whole. The litter contributes to the sustainability of the subsystem by returning to the soil the nutrients removed by the plants (AGUIAR et al., 2014); further, the biomass of the tree/shrub species stores nutrients (AGUIAR et al. 2014) and serves as food for the animals of the SP subsystem. The SP subsystem supplies emergy from the goat/sheep meat (83.3\%). The co-products that contributed the most in terms of emergy were improved soil quality and manure, which together represented $16.1 \%$ of the emergy produced in SP. The main contribution produced by the CAT was from soil quality, which represented $97.2 \%$ of the total production of the area 
(Table 2). The agroforestry system as a whole (AGROF), in addition to the emergy produced from meat (73.8\%), has as its main co-product an improvement in soil quality, which represents $24.8 \%$ of the total emergy produced in the system.

In the subsystem under traditional cultivation (AC), 97.6\% of the emergy produced came from crops (maize and sorghum), while the fallow areas contributed with an improvement in soil quality (F6), tree biomass (F6 and F9) and litter (F9) (Table 3).

\section{Emergy indices}

Comparing all the subsystems, it can be seen that the area under fallow for six years (F6) required the least amount of total emergy $(\mathrm{Y})$, followed by the area under preserved caatinga (CAT) (Table 4). On the other hand, the emergy needed to support meat production (SP) was the most of all the subsystems. Between the areas of maize and sorghum production, the agroforestry system (ASP) required a larger quantity of emergy compared to the traditional system (AC), but use of this emergy was more efficient in the first system, which can be seen in its smaller transformity (Table 4). The values for transformity (Tr) obtained for the subsystems and for the systems as a whole (AGROF and TRAD) (Table 4) were lower than those seen in other studies, such as Agostinho et al. (2008), Barros et al. (2009) and Alfaro-Arguello et al. (2010). The lower values for Tr obtained for the systems under study indicate greater efficiency in energy conversion.

Among the subsystems under study, the area under CAT presented a high Yield Ratio (EYR), indicating little investment from the economy in relation to the emergy from nature that supports this subsystem. The values for EYR were similar to those found by Odum (1996) and Bastianoni et al. (2001) for conventional agricultural systems, but lower than those observed by Agostinho et al. (2008) for organic and conventional areas of production, and by Lu et al. (2006), evaluating an integrated system of fish-farming, pasture, orchard and forest. The lower values seen in the systems studied here are due to less use of resources from the economy, and demonstrate that these systems are less dependent on economic resources (BROWN et al., 1997) as they are based on the use of local services and resources. On the other hand, the use of EYR as an indicator of emergy efficiency should be viewed with caution, since high values for EYR may be the result of the heavy use of non-renewable natural resources, resulting in the use of few resources from the economy.

The emergy investment ratio (EIR) indicates the amount of emergy from the economy that the systems use for each unit of emergy from nature. In planning agroecosystems, actions should be prioritised that reduce this index, since current global trends point to the need for production systems that maximise the use of renewable natural resources and require less economic investment (AGOSTINHO et al., 2008). With regards to this index (EIR), it can be seen that SP achieved a considerably higher value than the other sub-areas, which suggests that it is more dependent on resources coming from the economy. The EIR value of SP indicates that for every solar emjoule supplied by nature, 33 seJ are needed from the economy. However, since most of these resources are obtained in the ASP subsystem, the EIR of the agroforestry model (AGROF) is smaller, requiring 2.45 seJ from the economy for each solar emjoule used (Table 5). These results represent a better use of economic resources for the AGROF model, which, through the integration of 
agricultural and pastoral activities, allows part of the demand for input from the economy, necessary for animal production, to be produced on the same property. The EIR found for the AGROF model is greater than the values seen for ecologically-based farming systems (ORTEGA et al., 2005; FRANCESCATTO et al., 2008) and for agroforestry systems (LEFROY et al., 2003), but is lower than that seen by Agostinho et al. (2010) for organic orchards, annual crops and coffee plantations, and similar to that found by Eurich et al. (2013) for a family-based dairy production system. The investment ratio (EIR) seen under the TRAD management was lower than that seen under AGROF management, since two of the three subsystems evaluated in TRAD are fallow and do not use services from the economy. The EIR of this model (TRAD) was low (Table 4), but was similar to that observed by Agostinho et al. (2010) for areas planted with trees, and by Lefroy et al. (2003) for agroforestry systems.

Table 4: Input, output and emergy indices of the agroforestry (AGROF) and traditional (TRAD) production systems and their subsystems.

\begin{tabular}{|c|c|c|c|c|c|c|c|c|c|}
\hline \multirow{2}{*}{ Item/index } & & \multicolumn{4}{|c|}{ Agroforestry system } & \multicolumn{4}{|c|}{ Traditional system } \\
\hline & & ASP & SP & CAT & AGROF & $\mathrm{AC}$ & F6 & F9 & TRAD \\
\hline $\begin{array}{l}\text { Renewable natural resources - } \mathrm{R} \\
\text { (seJ/ha/year) }\end{array}$ & & $3.1 \mathrm{E}+15$ & $3.4 \mathrm{E}+15$ & $3.4 \mathrm{E}+15$ & $3.3 \mathrm{E}+15$ & $3.1 \mathrm{E}+15$ & $3.4 \mathrm{E}+15$ & $3.4 \mathrm{E}+15$ & $3.3 \mathrm{E}+15$ \\
\hline $\begin{array}{l}\text { Non-renewable natural resources } \\
\text { (seJ/ha/year) }\end{array}$ & $-\quad N$ & $9.0 \mathrm{E}+15$ & $2.5 \mathrm{E}+13$ & $7.9 \mathrm{E}+11$ & $3.0 \mathrm{E}+15$ & $9.8 \mathrm{E}+15$ & $5.8 \mathrm{E}+11$ & $1.8 \mathrm{E}+15$ & $3.9 \mathrm{E}+15$ \\
\hline Total natural resources $(\mathrm{I}=\mathrm{R}+\mathrm{N})$ & & $1.2 \mathrm{E}+16$ & $3.4 \mathrm{E}+15$ & $3.4 \mathrm{E}+15$ & $6.3 E+15$ & $1.3 \mathrm{E}+16$ & $3.4 \mathrm{E}+15$ & $5.2 \mathrm{E}+15$ & $7.2 E+15$ \\
\hline \multicolumn{10}{|l|}{ Materials - M } \\
\hline Renewable $M_{R}$ (seJ/ha/year) & & $4.7 \mathrm{E}+15$ & $6.5 E+16$ & $0.0 \mathrm{E}+00$ & $3.0 \mathrm{E}+13$ & $2.1 \mathrm{E}+11$ & $0.0 \mathrm{E}+00$ & $0.0 \mathrm{E}+00$ & $7.1 \mathrm{E}+10$ \\
\hline Non-renewable $\mathrm{M}_{\mathrm{N}}$ (seJ/ha/year) & & $2.0 \mathrm{E}+15$ & $4.5 \mathrm{E}+16$ & $0.0 \mathrm{E}+00$ & $3.0 \mathrm{E}+15$ & $2.1 \mathrm{E}+13$ & $0.0 \mathrm{E}+00$ & $0.0 \mathrm{E}+00$ & $7.0 \mathrm{E}+12$ \\
\hline \multicolumn{10}{|l|}{ Services $-\mathrm{S}$} \\
\hline Renewable $S_{R}$ (seJ/ha/year) & & $2.2 \mathrm{E}+16$ & $1.1 \mathrm{E}+16$ & $4.7 \mathrm{E}+14$ & $1.1 \mathrm{E}+16$ & $1.5 \mathrm{E}+16$ & $0.0 \mathrm{E}+00$ & $0.0 \mathrm{E}+00$ & $4.8 \mathrm{E}+15$ \\
\hline /year) & & $2.4 \mathrm{E}+15$ & $1.3 \mathrm{E}+15$ & $5.5 E+13$ & $1.3 \mathrm{E}+15$ & $1.6 \mathrm{E}+15$ & $0.0 \mathrm{E}+00$ & $0.0 \mathrm{E}+00$ & $5.4 \mathrm{E}+14$ \\
\hline Economic resources $(F=M+S)$ & & $3.1 \mathrm{E}+16$ & $1.1 \mathrm{E}+17$ & $5.3 E+14$ & $1.5 \mathrm{E}+16$ & $1.6 \mathrm{E}+16$ & $0.0 \mathrm{E}+00$ & $0.0 \mathrm{E}+00$ & $5.4 \mathrm{E}+15$ \\
\hline $\begin{array}{l}\text { Total input emergy }(\mathrm{Y}=\mathrm{I}+\mathrm{F}) \\
\text { (seJ/ha/year) }\end{array}$ & & $4.3 \mathrm{E}+16$ & $1.3 \mathrm{E}+17$ & $3.9 \mathrm{E}+15$ & $2.2 \mathrm{E}+16$ & $2.9 \mathrm{E}+16$ & $3.4 \mathrm{E}+15$ & $5.2 \mathrm{E}+15$ & $1.3 \mathrm{E}+16$ \\
\hline Produced emergy - Ep (J/h year) & & $3.0 \mathrm{E}+11$ & $5.8 \mathrm{E}+11$ & $1.5 \mathrm{E}+12$ & $7.3 E+11$ & $1.2 \mathrm{E}+11$ & $2.2 \mathrm{E}+11$ & $1.5 \mathrm{E}+11$ & $1.6 \mathrm{E}+11$ \\
\hline Transformity - Tr (seJ J) & & $1.5 \mathrm{E}+05$ & $2.2 \mathrm{E}+05$ & $2.6 \mathrm{E}+03$ & $3.0 \mathrm{E}+04$ & $2.4 \mathrm{E}+05$ & $1.6 \mathrm{E}+04$ & $3.6 \mathrm{E}+04$ & $7.8 \mathrm{E}+04$ \\
\hline Yield ratio - EYR & & 1.39 & 1.03 & 7.50 & 1.41 & 1.80 & - & - & 2.33 \\
\hline Investment ratio - EIR & & 2.56 & 33.33 & 0.15 & 3.19 & 1.25 & 0.00 & 0.00 & 0.75 \\
\hline Envir & & 0.46 & 0.58 & 0.01 & 0.50 & 0.65 & 0.00 & 0.54 & 0.54 \\
\hline Emergy renewability index $\% \mathrm{R}$ & & 68.68 & 63.17 & 98.59 & 66.65 & 60.76 & 99.98 & 64.95 & 64.92 \\
\hline Emergy sustainability index (ESI) & & 3.05 & 1.76 & 523.44 & 2.81 & 2.78 & - & - & 4.31 \\
\hline
\end{tabular}

ASP: Agrosilvopastoral; SP: silvopastoril; CAT: Preserved caatinga; AGROF: Agroforestry production model, comprising the ASP, SP and CAT subsystems. AC: Traditional cultivation; F6: Traditional cultivation lying fallow for six years; F9: Traditional cultivation lying fallow for nine years; TRAD: Traditional production model, comprising the AC, F6 and F9 subsystems.

All the systems and sub-systems being assessed had values for the Environmental Loading Rate (ELR) of less than two, indicating low impact on the environment (BROWN et al., 2004). The low environmental impact (ELR) seen in AGROF shows that it allows efficient use of natural resources, and can be indicated for use in improving production and environmental conservation. It is worth noting that these systems, just as other agroecological systems (ORTEGA et al., 2005; AGOSTINHO et al., 2008; FRANCESCATTO et al., 2008) considerably reduce the environmental impact caused by the conventional agriculture adopted in Brazil (ORTEGA et al., 2005; AGOSTINHO et al., 2008; FRANCESCATTO et al., 2008; CAVALETT et al., 2009).

The F6 and CAT subsystems display the best renewability indices (\%R), and CAT the best emergy sustainability (ESI), as it uses a greater proportion of resources from nature and minimises losses due to 
erosion, resulting in a higher return on the emergy utilised and a lower environmental load. The remaining subsystems showed values for $\% \mathrm{R}$ of more than $60 \%$ renewability, which indicates that they have great potential for long-term maintenance, and can overcome possible economic stress (LEFROY et al, 2003; BROWN et al., 2004). The SP subsystem had the lowest ESI, due to the high emergy costs from the economic inputs required for animal production. Similar results were found by Lu et al. (2006) and Fonseca et al. (2016) for areas of pasture in other regions (China an Portugual). Whereas Eurich et al. (2013) found far lower values for bovine milk production under family farming in Brazil. Those authors point to the excessive use of external resources and the low use of renewable resources as factors contributing to the low sustainability indices of animal production.

The emergy sustainability indices seen for the AGROF and TRAD models show that they contribute to the sustainability of agricultural production, since they result in better performance, being superior to production systems that use holistic and conventional concepts (LU et al., 2006; ALFARO-ARGUELLO et al., 2010, EURICH et al., 2013). The best performance for the systems studied in the Brazilian semi-arid region may have occurred due to the increase in forest cover in the areas of agricultural production), as well as the integration between different agricultural activities, just as noted by Wu et al. (2015). It should be noted that this increase in the indicators of sustainability leads to improvements in the productivity of the agroecosystems (ALFARO-ARGUELLO et al., 2010).

\section{CONCLUSIONS}

Adopting techniques that integrate agricultural, forestry and pastoral activities to improve efficiency in the use of materials and energy can bring great benefits for the agroecosystem and for the economy, since the integration promoted by the agroforestry system permitted better emergy efficiency. This agroforestry system can therefore be indicated for improving agricultural production in the semi-arid region, as well as conserving the native vegetation of the caatinga. However, techniques for the improvement of forage production must be increased, to improve the performance of the subsystem of animal production.

The traditional system uses a larger amount of natural resources, generating greater transformity in the production process, i.e. less emergy efficiency. In addition, this system reduces the formation of internal stocks and flows, such as tree biomass, biomass for grazing, and litter. The management adopted in the subsystem under production causes such environmental damage as erosion and the loss of soil quality. Lessening of this damage, as is promoted during fallow periods, incurs a greater demand of emergy. This type of management is therefore not recommended, as it utilises natural resources inefficiently, and requires a large amount of land for its use, due to the need for fallow areas.

\section{REFERENCES}

AGOSTINHO, F.; DINIZ, G.; SICHE, R.; ORTEGA, E.. The use of emergy assessment and the geographical information system en the diagnosis of small family farms in Brazil. Ecol. Model., v.210, p.37-57, 2008. DOI:

http://doi.org/10.1016/j.ecolmodel.2007.07.007
AGOSTINHO, F.; AMBRÓSIO, L. A.; ORTEGA, E.. Assessment of a large watershed in Brazil using Emergy Evaluation and Geographical Information System. Ecol. Model., v.221, p.1209-1220, 2010. DOI: 
http://doi.org/10.1016/j.ecolmodel.2009.12.019

AGUIAR, M. I.; MAIA. S. M. F.; XAVIER, F. A. S.; MENDONÇA, E. S.; ARAÚJO FILHO, J. A.; OLIVEIRA, T. S.. Sediment, nutrient and water losses by water erosion under agroforestry systems in the semi-arid region in northeastern Brazil. Agroforest Syst., v.79, p.277-289, 2010. DOI: http://doi.org/10.1007/s10457-010-9310-2

AGUIAR, M. I.; FIALHO, J. S.; ARAÚJO, F. C. S.; CAMPANHA, M.M.; OLIVEIRA, T. S.. Does biomass production depend on plant community diversity?. Agroforestry Syst. v.87, p.699711. DOI: http://doi.org/10.1007/s10457-012-9590-9

AGUIAR, M. I.; FIALHO, J. S.; CAMPANHA, M. M.; OLIVEIRA, T. S.. Carbon sequestration and nutrient reserves under different land use systems. Rev. Árvore, v.38, p.81-93, 2014. DOI: $\underline{\text { http://doi.org/10.1590/S0100-67622014000100008 }}$

AGUIAR, M. I.; FIALHO, J. S.; CAMPANHA, M. M.; OLIVEIRA, T. S.. Florística e estrutura vegetal em áreas de Caatinga sob diferentes sistemas de manejo. Pesquisa Florestal Brasileira, v.39, p.1-11

DOI: https://doi.org/10.4336/2019.pfb.39e201801715

ALFARO-ARGUELLO, R.; DIEMONT, S. A. W.; FERGUSON, B. G.; MARTIN, J. F.; NAHED-TORAL, J.; ÁLVAREZ-SOLÍS, J. D.; RUÍZ, R. P.. Steps toward sustainable ranching: An emergy evaluation of conventional and holistic management in Chiapas, Mexico. Agricultural Systems, v.103, p.639-646, 2010. DOI: http://doi.org/10.1016/j.agsy.2010.08.002

ARAÚJO FILHO, J. A.; CARVALHO, F. C.. Sistemas de produção agrossilvipastoril para o semi-árido nordestino. In: CARVALHO, M. M.; ALVIM, M. J.; CARNEITO, J. C.. Sistemas agroflorestais pecuários: opções de sustentabilidade para áreas tropicais e subtropicais. Brasília: FAO, 2001. p.101-110.

BARROS, I.; BLAZY, J. M.; RODRIGUES, G. S.; TOURNEBIZE, R.; CINNA, J. P.. Emergy evaluation and economic performance of banana cropping systems in Guadeloupe (French West Indies). Agriculture, Ecosystems and Environment, v.129, p.437-449, 2009. DOI: http://doi.org/10.1016/j.agee.2008.10.015

BASTIANONI, S.; MARCHETTINI, N.; PANZIERI, M.; TIEZZI, E.. Sustainability assessment of a farm in the Chianti area (Italy). J. Clean. Prod., v.9, p.365-373. DOI: http://dx.doi.org/10.1016/S0959-6526(00)00079-2

BLOC, A. F. R.; CARVALHO, F. C.; GOMES, T. C. L.; ARAÚJO FILHO, J. A.; STIVARI, T. S. S.; SARTORELLO, G. L.. Análise econômica da produção de ovinos em sistema agropastoris sob diferentes regimes alimentares e de acasalamento, Estado do Ceará, Período 1999 a 2002. Informações Econômicas, v.46, p.05-12, 2016.

BRASIL. Ministério das Minas e Energia. Folhas SB. 24/25 Jaguaribe/Natal 1981.

Geologia/Geomorfologia/Pedologia/Vegetação/Uso Potencial da Terra. Rio de Janeiro, 1981.

BROWN, M. T.; ULGIATI, S.. Emergy-based indices and ratios to evaluate sustainability: monitoring economies and technology toward environmentally sound innovation. Ecological Engineering, v.9, p.51-69, 1997. DOI: https://doi.org/10.1016/S0925-8574(97)00033-5
BROWN, M. T.; ULGIATI, S.. Emergy analysis and environmental accounting. Encyclopedia of Energy, v.2, p.329-354, 2004. DOI: http://doi.org/10.1016/B0-12176480-X/00242-4

CARVALHO, F. C.. Sistema de produção agrossilvipastoril para a região semiárida do Nordeste do Brasil. Tese (Doutorado em Fitotecnia) - Universidade Federal de Viçosa, Viçosa, 2003.

CAVALETTE, O.; ORTEGA, E.. Emergy, nutrients balance, and economic assessment of soybean production and industrialization in Brazil. J. Clean. Prod., v.17, p.762-771, 2009. DOI: http://doi.org/10.1016/j.jclepro.2008.11.022

COELHO, O.; ORTEGA, E.; COMAR, V.. Balanço de Emergia do Brasil (Dados de 1996, 1989 e 1981). In: ORTEGA, E.. Engenharia Ecológica e Agricultura Sustentável. Campinas: UNICAMP, 2003.

COLE, M. M.. Cerrado, Caatinga and Pantanal: the distribution and origin of the savanna vegetation of Brazil. The Geografic Journal, v.126, p.168-179, 1960. DOI: http://doi.org/10.2307/1793957

DRUMOND, M. A.; MORGADO, L. B.; RIBASKI, J.; ALBUQUERQUE, S. G.; CARVALHO, O. M.. Contribuição da Embrapa Semi-árido para o desenvolvimento dos sistemas agroflorestais no Semi-árido brasileiro. Agrossilvicultura, v.1, p.145-153, 2004.

EURICH, J.; WEIRICH NETO, P. H.; ROCHA, C. H.. Índices emergéticos de sustentabilidade da produção de base familiar em Palmeiras, Paraná, Brasil. Revista Ceres, v.60, p.332-338, 2013. DOI: http://dx.doi.org/10.1590/S0034737X2013000300005

FIALHO, J. S.; AGUIAR, M. A.; MAIA, L. S.; MAGALHÃES, R. B. ARAÚJO, F. C. S.; CAMPANHA, M. M.; OLIVEIRA, T. S.. Soil quality, resistance and resilience in traditional agricultural and agroforestry ecosystems in Brazil's semiarid region. African Journal of Agricultural Research, v.8, p.5020-5031, 2013. DOI: https://doi.org/10.5897/AJAR2013.6712

FRANCESCATTO, G.; AGOSTINHO, F.; NACHTIGALL, G. R.; NOBRE JUNIOR, A. A.; ORTEGA, E.. Emergy and economic diagnosis of apple production system in south of Brazil. In: PROCEEDINGS OF BIENNIAL EMERGY CONFERENCE, 5. Anais. Gainesville, 2008.

FONSECA, A. M. P.; MARQUES, C. A. F.; PINTO-CORREIA, T.; CAMPBELL, D. E.. Emergy of a silvo-pastoral system, a case study in Southern Portugal. Agroforest System, v.90, p.137197, 2016. DOI: http://doi.org/10.1007/s10457-015-9888-5

INMET Instituto Nacional de Meteorologia. Dados metereológicos. INMET, 2012.

IPECE. Instituto de Pesquisa e Estratégia Econômica do Ceará. Perfil Básico Municipal, Sobral. Fortaleza: SEPLAN, 2016.

LEFROY, E.; RYDBERG. T.. Emergy evaluation of three cropping systems in southwestern Australia. Ecological Modelling, v.161, p.195-211, 2003.

https://doi.org/10.1016/S0304-3800(02)00341-1 
LU, H.; CAMPBELL, D. E.; LI, Z.; REN, H.. Emergy synthesis of an agro-forest restoration system in lower subtropical Chine. Ecological Engineering, v.27, p.175-192, 2006. DOI: https://doi.org/10.1016/j.ecoleng.2005.12.002

LU, H.; KANG, E.; CAMPBELL, D. E.; REN, H.; TAN, Y.; FENG, R.; LUO, J.; CHEN, F.. Emergy and economic evaluations of four fruit production systems on reclaimed wetlands surrounding the Pearl River Estuary, China. Ecological Engineering, v.35, p.1743-1757, 2009. DOI: https://doi.org/10.1016/i.ecoleng.2009.08.001

MARIN, A. M.; MENEZES, R. S. C.; SILVA, E. D.; SAMPAIO, E. V. S. B.. Efeito da Gliricidia sepium sobre nutrientes do solo, microclima e produtividade do milho em sistemas agroflorestais no agreste paraibano. Revista Brasileira de Ciência do Solo, v.30, p.555-564, 2006. DOI: http://dx.doi.org/10.1590/S0100-06832006000300015.

NAIR, P. K. R.. An introduction to agroforestry. Kluwer: Dordrecht, 1993.

NOGUEIRA, R. S.; OLIVEIRA, T. S.; TEIXEIRA, A. S.; ARAÚJO FILHO, J. A.. Redistribuição de carbono orgânico e fósforo pelo escoamento superficial em sistemas agrícolas convencionais e agroflorestais no semiárido cearense. Revista Ceres, v.55, p.327-337, 2008.

ODUM, H. T.. Ecological and general systems. Niwot: Universidade Press of Colorado, 1994.

ODUM, H. T.. Environmental Accouting: emergy and environmental decision making. New York: John Wiley \& Sons, Inc., 1996.

ODUM, H. T.. Hardbook of emergy evaluation Gainesville: Center for Environmental Policy, Enviromental Engeneering Sciences, University of Florida. 2000.

ORTEGA, E.. Manual de cálculo de emergia. Campinas: UNICAMP, 2002.
ORTEGA, E.; CAVALETT, O.; BONIFÁCIO, R.; WATANABE, M.. Brazilian soybean production: emergy analysis with an expanded scope. Bulletin of Science, Technology \& Society, v.25, p.323-334, 2005. DOI: https://doi.org/10.1177/0270467605278367

PALÁCIO, H. A. Q.; ANDRADE, E. M.; SANTOS, J. C. N.; ARAÚJO NETO, J. R.; BRASIL, P. P.. Emergy evaluation of semi-arid watersheds under different management strategies. American Society of Agricultural and Biological Engineers, v.56, p.1357-1363, 2013.

RODRIGUEZ, G. R.; BROWN, M. T.; ODUM, H. T.. Sameframe - Sustainability Assessment Methodology Framework. In: PROCCEDINGS OF INTERNACIONAL WORKSHOP ADVANCES IN ENERGY STUDIES: RECONSIDERING THE IMPORTANCE OF ENERGY, PORTO VENERE, 3. Anais. 2002. p.605-612.

RONCON, T. J.; BESKOW, P. R.; ORTEGA, E.; MARGARIDO, L. A. C.; DINIZ JUNIOR., G. M.. Valoração ecológica aplicada a áreas de preservação permanente. Revista Brasileira de Agroecologia, v.7, p.3-15, 2012.

SILVA, G. L.; LIMA, H. V.; CAMPANHA, M. M.; GILKES, R. J.; OLIVEIRA, T. S.. Soil physical quality of Luvisols under agroforestry, natural vegetation and conventional crop management systems in the Brazilian semi-arid region. Geoderma, v.167-168, p.61-70, 2011. DOI: https://doi.org/10.1016/i.geoderma.2011.09.009

ULGIATI, S.; BROW, M. T.; BASTIANONI, S.; MARCHETTINI, N.. Emergy-based indices and ratios to evaluate the sustainable use of resources. Ecological Engineering, v.5, p.519-531, 1995. DOI: https://doi.org/10.1016/0925-8574(95)00043-7

WU, X.; WU, F.; WU, J.; SUN, J.. Emergy-Based Sustainability Assessment for a Five-in-One Integrated Production System of Apple, Grass, Pig, Biogas, and Rainwater on the Loess Plateau, Northwest China. Agroecology and Sustainable Food Systems, v.39, p.666-690, 2015. DOI: https://doi.org/10.1080/21683565.2015.1015200

A CBPC - Companhia Brasileira de Produção Científica (CNPJ: 11.221.422/0001-03) detém os direitos materiais desta publicação. Os direitos referem-se à publicação do trabalho em qualquer parte do mundo, incluindo os direitos às renovações, expansões e disseminações da contribuição, bem como outros direitos subsidiários. Todos os trabalhos publicados eletronicamente poderão posteriormente ser publicados em coletâneas impressas sob coordenação da Sustenere Publishing, da Companhia Brasileira de Produção Científica e seus parceiros autorizados. Os (as) autores (as) preservam os direitos autorais, mas não têm permissão para a publicação da contribuição em outro meio, impresso ou digital, em português ou em tradução. 